\title{
Influence of temperature on the immune response of juvenile summer flounder, paralichthys dentatus, and its role in the elimination of Trypanoplasma bullocki infections
}

Joseph P. Sypek

College of William and Mary - Virginia Institute of Marine Science

Follow this and additional works at: https://scholarworks.wm.edu/etd

Part of the Fresh Water Studies Commons, and the Oceanography Commons

\section{Recommended Citation}

Sypek, Joseph P., "Influence of temperature on the immune response of juvenile summer flounder, paralichthys dentatus, and its role in the elimination of Trypanoplasma bullocki infections" (1982). Dissertations, Theses, and Masters Projects. Paper 1539616871.

https://dx.doi.org/doi:10.25773/v5-3p8p-jr26

This Dissertation is brought to you for free and open access by the Theses, Dissertations, \& Master Projects at W\&M ScholarWorks. It has been accepted for inclusion in Dissertations, Theses, and Masters Projects by an authorized administrator of W\&M ScholarWorks. For more information, please contact scholarworks@wm.edu. 


\section{INFORMATION TO USERS}

This reproduction was made from a copy of a document sent to us for microfilming. While the most advanced technology has been used to photograph and reproduce this document, the quality of the reproduction is heavily dependent upon the quality of the material submitted.

The following explanation of techniques is provided to help clarify markings or notations which may appear on this reproduction.

1. The sign or "target" for pages apparently lacking from the document photographed is "Missing Page(s)". If it was possible to obtain the missing page(s) or section, they are spliced in to the film along with adjacent pages. This may have necessitated cutting through an image and duplicating adjacent pages to assure complete continuity.

2. When an image on the film is obliterated with a round black mark, it is an indication of either blurred copy because of movement during exposure, duplicate copy, or copyrighted materials that should not have been filmed. For blurred pages, a good image of the page can be found in the adjacent frame. If copyrighted materials were deleted, a target note will appear listing the pages in the adjacent frame.

3. When a map, drawing or chart, etc., is part of the material being photographed, a definite method of "sectioning" the' material has been followed. It is customary to begin filming at the upper left hand corner of a large sheet and to continue from left to right in equal sections with small overlaps. If necessary, sectioning is continued again-beginning below the first row and continuing on until complete.

4. For illustrations that cannot be satisfactorily reproduced by xerographic means, photographic prints can be purchased at additional cost and inserted into your xerographic copy. These prints are available upon request from the Dissertations Customer Services Department.

5. Some pages in any document may have indistinct print. In all cases the best available copy has been filmed.

\section{University Microfilms International}


1 
Sypek, Joseph Paul

INFLUENCE OF TEMPERATURE ON THE IMMUNE RESPONSE OF JUVENILE SUMMER FLOUNDER, PARALICHTHYS DENTATUS, AND ITS ROLE IN THE ELIMINATION OF TRYPANOPLASMA BULLOCKI INFECTIONS

\author{
University \\ Microfilms \\ International 300 N. Zeeb Road, Ann Arbor, MI 48106
}


PLEASE NOTE:

In all cases this material has been filmed in the best possible way from the available copy. Problems encountered with this document have been identified here with a check mark

1. Glossy photographs or pages

2. Colored illustrations, paper or print

3. Photographs with dark background

4. Illustrations are poor copy

5. Pages with black marks, not original copy

6. Print shows through as there is text on both sides of page

7. Indistinct, broken or small print on several pages

8. Print exceeds margin requirements

9. Tightly bound copy with print lost in spine

10. Computer printout pages with indistinct print

11. Page(s) lacking when material received, and not available from school or author.

12. Page(s) seem to be missing in numbering only as text follows.

13. Two pages numbered - Text follows.

14. Curling and wrinkled pages

15. Other

\section{University Microfilms International}




\begin{abstract}
INFLUENCE OF TEMPERATURE ON THE IMMUNE RESPONSE OF JUVENILE SUMMER FLOUNDER, PARALICHTHYS DENTATUS, AND ITS ROLE IN THE ELIMINATION OF TRYPANOPLASMA BULLOCKI INFECTIONS
\end{abstract}

\author{
A Dissertation \\ Presented to \\ The Faculty of the School of Marine Science \\ The College of William and Mary in Virginia \\ In Partial Fulfillment \\ of the Requirements for the Degree of \\ Doctor of Philosophy
}

by

Joseph P. Sypek

1982 
APPROVAL SHEET

This dissertation is submitted in partial fulfillment of the requirements for the degree of Doctor of Philosophy in Marine Science

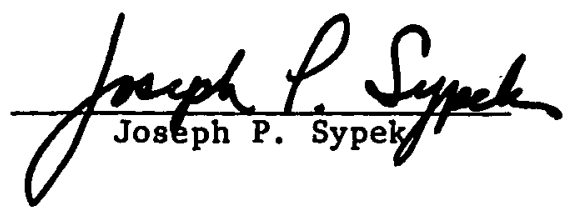

Approved, August 1982

Eugene M. Bupersan

Eugene M. Burreson, PhD.

Chairman

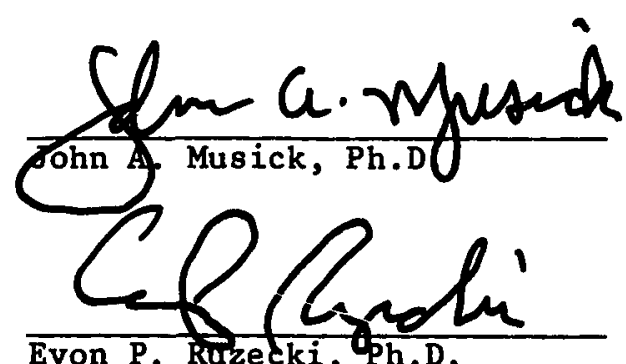

Evan P. Ruzeटki, फh.D.

Y)oughaf. And ss ow

National fish Health Research Laboratory

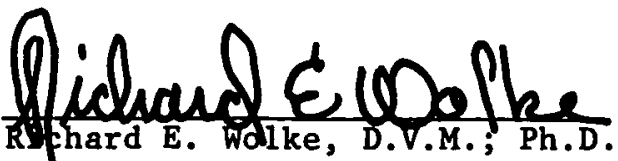

Unfversity of Rhode Island

ii 
TABLE OF CONTENTS

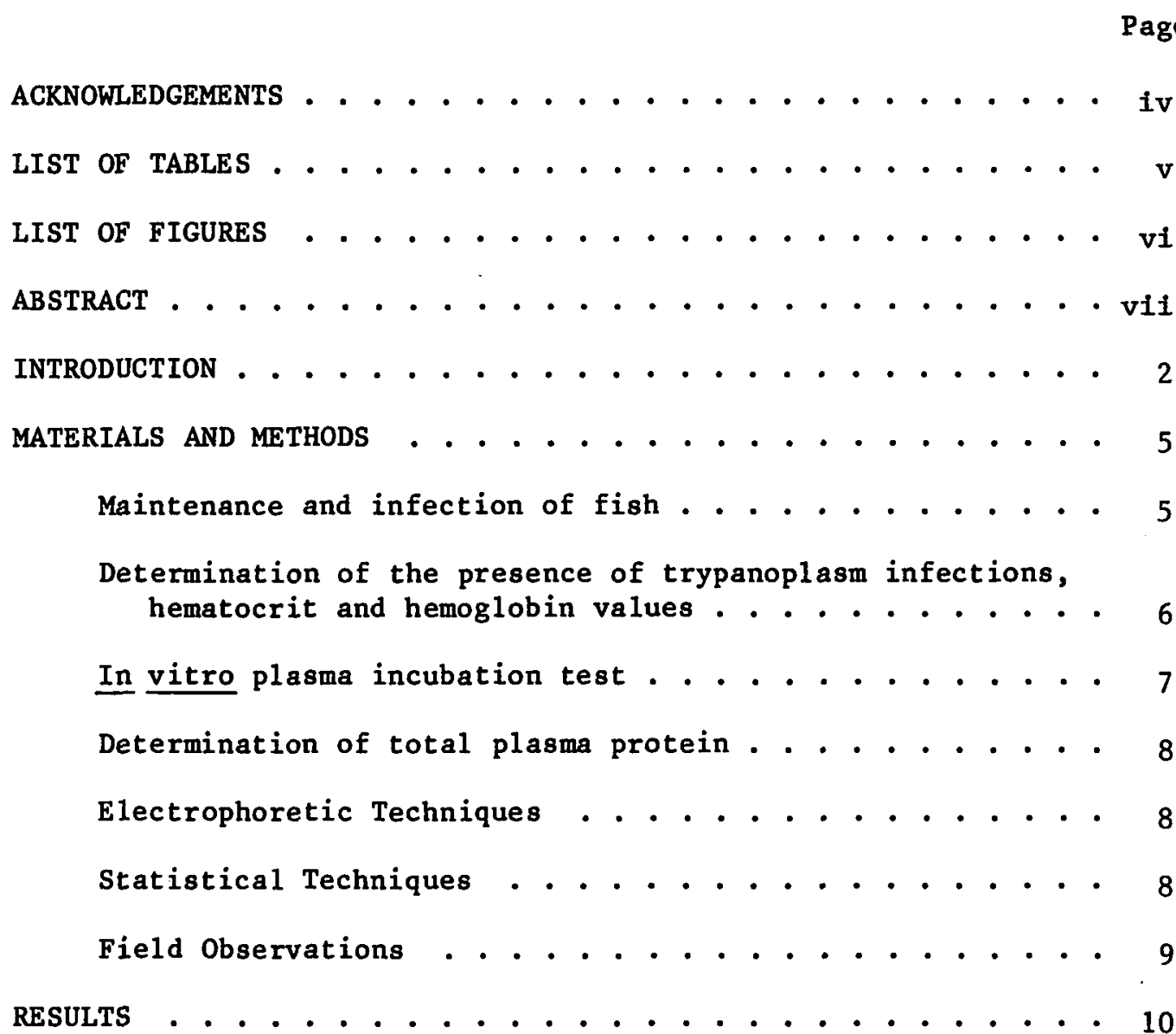

I. Experimental Observations . . . . . . . . . 10

Hematocrit and hemoglobin values ......... 10 Observations on the course of experimental infections. 16 In vitro plasma incubation tests .......... 16 Serum protein patterns ........... . . 24

II. Field Observations .............. 24 DISCUSSION . . . . . . . . . . . . . . . 42 42 APPENDICES . . . . . . . . . . . . . . . 47 LITERATURE CITED . . . . . . . . . . . . . . . 54 $\operatorname{vITA} \cdot . \cdot . \cdot . \cdot . \cdot . \cdot . \cdot . \cdot . \cdot 661$ 


\section{ACKNOWLEDGEMENTS}

The writer wishes to express his sincere appreciation to Dr. Eugene M. Burreson for his encouragement and guidance throughout the course of this investigation. A special debt of gratitude is expressed to Mr. David E. Zwerner for his invaluable assistance and informative advice which helped make this work a reality. The author is also indebted to Drs. John A. Musick, Evon P. Ruzecki, Douglas P. Anderson and Richard E. Wolke for their support and critical review of the manuscript.

Many additional efforts contributed to the completion of this work, particularly those of Maura E. Jansen, Paul D. Gerdes, Hugh A. Brooks and Glenn R. Delaney; to them special thanks are due, and to Dr. Robert Diaz for his assistance in statistical analysis of data.

Many thanks go out to the members of the VIMS community whose company stimulated both academic excellence and refreshing solacement.

I would also like to thank Miss Annette Stubbs for typing the many drafts and final copy of this paper.

Finally, special thanks go to my family, Stanley, Mary, and Marianne for their endless love, understanding and support; to them I dedicate this work. 
Table

Page

1 Statistical comparison of blood determinations between Trypanoplasma bullocki infected (Group 1) and noninfected (Group 2) juvenile summer flounder . . . . . . . . 15

2 Statistical comparison of blood determinations between Trypanoplasma bullocki infected (Group 1) and injected (Group 3) juvenile summer flounder . . . . . . . . . .

3 Trypanoplasma bullocki incubated in vitro with plasma from juvenile summer flounder, Paralichthys dentatus from experimental infections................ 20

4 Mean protein concentrations \pm 1 standard deviation expressed in $\mathrm{gm} / 100 \mathrm{ml}$ from plasma of Trypanoplasma bullocki infected and noninfected juvenile summer flounder .................. 35

5 Statistical comparison of protein determinations among Trypanoplasma bullocki infected and noninfected juvenile sumer flounder ................ 36

6 Trypanoplasma bullocki incubated in vitro with plasma from juvenile summer flounder, Paralichthys dentatus taken from the lower Chesapeake Bay ............

7 Noninfected subadult and adult summer flounder taken from the lower Chesapeake Bay and Mid-Atlantic Bight displaying no trypanoplasmacidal titers . . . . . . . . . . .

\section{APPENDICES}

I Experimental observations on Trypanoplasma bullocki infected and noninfected juvenile summer flounder . . . . 47

II Protein concentrations $(\mathrm{gm} / 100 \mathrm{ml})$ from plasma of Trypanoplasma bullocki infected and noninfected juvenile summer flounder................. 50

III Field observations on Trypanoplasma bullocki infected and noninfected juvenile summer flounder taken from the lower Chesapeake Bay 
LIST OF FIGURES

Figure

1 Hematologica1 data of Trypanoplasma bullocki infected and noninfected juvenile summer flounder . . . . . . . . . 11

2 Hematological data of Trypanoplasma bullocki injected summer flounder maintained at $5^{\circ} \mathrm{C}$ for 12 weeks . . . . . . 13

3 Course of Trypanoplasma bullocki infections in juvenile summer flounder maintained at elevating water temperatures

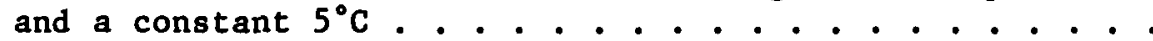

4 Peritoneal fluid smear from juvenile flounder held at $5^{\circ} \mathrm{C}$ showing both free and phagocytized T. bullocki . . . . . . 22

5 Electrophoretograms of human serum and juvenile infected summer flounder serum separated on cellulose polyacetate.

6 Electrophoretograms of sera from 4 juvenile summer flounder infected with Trypanoplasma bullocki at $5^{\circ} \mathrm{C}$. . . 27

7 Electrophoretograms of sera from 6 noninfected juvenile summer flounder at $24^{\circ} \mathrm{C}$. . . . . . . . . . . . . . 29

8 Electrophoretograms of sera from 5 juvenile summer flounder infected with Trypanoplasma bullocki at $24^{\circ} \mathrm{C}$. . 32

9 Intensity of T. bullocki infections in samples of juvenile summer flounder taken from the lower Chesapeake Bay during the spring of 1982 . . . . . . . . . . . . . . 37 


\begin{abstract}
Two groups of juvenile summer flounder maintained at $5^{\circ} \mathrm{C}$ were experimentally infected with the hemoflagellate Trypanoplasma bullocki. Another group maintained at $5^{\circ} \mathrm{C}$ was not infected. The water temperature of one infected group was raised stepwise to $12^{\circ} \mathrm{C}$, $18^{\circ} \mathrm{C}$, and $24^{\circ} \mathrm{C}$ for 2 to 3 weeks at each level. The other infected group was maintained at $5^{\circ} \mathrm{C}$ for 12 weeks, the duration of the experiment. In addition, juvenile flounder were collected over a temperature range of $6^{\circ} \mathrm{C}$ to $22^{\circ} \mathrm{C}$ from February to June, 1982 to monitor natural infections. Live T. bullocki were incubated in plasma from fish at each temperature to monitor the host's humoral response. Trypanoplasmacidal lysis occurred in experimental infections maintained at $24^{\circ} \mathrm{C}$ and in natural infections over a range of $10^{\circ} \mathrm{C}$ to $22^{\circ} \mathrm{C}$. Complete elimination of trypanoplasms occurred in experimental infections at $24^{\circ} \mathrm{C}$ and in natural infections at $22^{\circ} \mathrm{C}$. Differences in temperature where lytic activity occurred was mainly attributable to the short time exposure of experimental infections to increasing temperatures in contrast to that occurring in nature. Trypanoplasmacidal lysis with increasing water temperatures in flounder indicates that the fish's humoral immunity is responsible for the annual spring decline in prevalence and eventual elimination of $T$. bullocki infections. Elevated levels of macroglobulins were detecte $\bar{d}$ in the sera of juvenile flounder recovering from $\mathrm{T}$. bullocki infections, and this may be associated with antibody production in response to the parasite.
\end{abstract}


INFLUENCE OF TEMPERATURE ON THE IMMUNE RESPONSE OF

JUVENILE SUMMER FLOUNDER, PARALICHTHYS DENTATUS, AND

ITS ROLE IN THE ELIMINATION OF TRYPANOPLASMA BULLOCKI INFECTIONS 


\section{INTRODUCTION}

Kinetoplastid hemoflagellates of the genus Trypanoplasma are common parasites in the blood of marine and freshwater fishes throughout the world (Becker, 1977; Lom, 1979). The current status of research upon fish hemoflagellates has been extensively reviewed by Lom (1979). Trypanoplasma often behaves as a pathogen in freshwater fishes (Dyková and Lom, 1979; Lowe-Jinde, 1979, 1980; Putz, 1972; Wales and Wolf, 1955; Woo, 1979); however, the effects on the hosts, the immune reactions and conditions that result in pathogenicity have not been adequately researched and are not well understood (Lom, 1979). This is especially true of marine forms.

Trypanoplasma bullocki (Strout, 1965) is a kinetoplastid flagellate that occurs in the blood of a wide variety of marine and estuarine demersal fishes along the Atlantic coast of North America from the Gulf of Maine to the Gulf of Mexico (Strout, 1965; Laird and Bullock, 1969; Becker and Overstreet, 1979; Burreson and Zwerner, 1982). Trypanoplasma bullocki is transmitted by the piscicolid leech, Calliobdella vivida (Burreson, 1982). In the Chesapeake Bay region, the hemoflagellate is most often found in hogchoker, Trinectes maculatus, and juvenile summer flounder, Paralichthys dentatus (Burreson and Zwerner, 1982). Hogchoker are infected throughout the year, juvenile summer flounder are only infected from the fall through the spring. Flounder become infected soon after the leech vector hatches from the cocoon in the late fall, when water temperatures 
average about $17^{\circ} \mathrm{C}$ (Burreson and Zwerner, 1982). Prevalence of trypanoplasm infections in young flounder thereafter rapidly approaches $100 \%$ and remains near this level throughout the winter. Water temperatures during this period average $5^{\circ} \mathrm{C}$ or less and often drop to near $0^{\circ} \mathrm{C}$ for short periods. During the late spring as the water warms, the prevalence of $\underline{\mathrm{T}}$. bullocki in juvenile flounder rapidly declines, and no infected fish are found after early June when water temperatures average about $22^{\circ} \mathrm{C}$ (Burreson and Zwerner, 1982). Adult summer flounder usually do not co-occur with the leech vector and so are only rarely exposed to $\underline{T}$. bullocki.

Studies by Burreson and Zwerner (in press) indicate that moderate to heavy $\underline{T}$. bullocki infections are associated with depressed hematocrits, hemoglobin values and red cell counts. Tissue sections and organ smears from infected flounder suggest compensatory changes are associated with hemopoietic organs, particularly the spleen, e.g. splenomegaly (Burreson and $\mathrm{Zwerner,} \mathrm{in} \mathrm{press).} \mathrm{Lesions} \mathrm{are} \mathrm{apparent}$ in heavy infections where the hemoflagellates occur extravascularly invading the hemopoietic organs and flagellates are also present in large numbers in the resulting edematous fluid of the peritoneal cavity (Burreson and Zwerner, in press; Newman, 1978). In the lower Chesapeake Bay region $\underline{T}$. bullocki was responsible for mortalities of juvenile summer flounder during the winters of 1981 and 1982 (Burreson and Zwerner, in press).

Studies by Avtalion and others (Avtalion et al., 1973; Avtalion, 1981; Muroga and Egusa, 1969) suggest that temperatures below $10-15^{\circ} \mathrm{C}$ 
cause a complete or partial depression of the host immune response in temperate fish. With previously unchallenged individuals (Harris, 1973; Paterson and Fryer, 1974; Rijkers et al., 1980a, b; O'Neil1, 1980), low temperatures cause an extended latent period, thereby prolonging the time before antibody is detected. Similar temperature effects on immunity in fish trypanosome infections have been observed by Bacrow $(1954,1955)$ and Cottrel1 (1977a).

The purpose of this investigation was to determine whether the spring decline in the prevalence of $\underline{T}$. bullocki infections in juvenile flounder resulted from an enhanced immune response caused by increasing temperature. 
MATERIALS AND METHODS

\section{Maintenance and Infection of Fish}

Summer flounder $160-210 \mathrm{~mm}$ in length less than 1 year old were maintained at ambient temperatures in an aerated, filtered water system at a salinity of approximately $22 \%$. Fish were fed daily with live shrimp, Palaemonetes pugio or Crangon septemspinosa, and killifish, Fundulus spp., depending upon availability. Each fish was examined for hemoflagellates prior to the experiment; the uninfected individuals were randomly divided into 4 groups and held separately at $13^{\circ} \mathrm{C}$. The temperature of $13^{\circ} \mathrm{C}$ approximates the temperature at which T. bullocki appears annually in summer flounder (Burreson and Zwerner, 1982). The 35 individuals to be infected by leech (Group 1) were placed in individual glass bowls containing 1 leech infected with $\underline{T}$. bullocki. The $33 \mathrm{fish}$ in the control group (Group 2) were placed in individual bowls containing 1 uninfected leech. After the leeches had fed and been removed, both groups were initially maintained separately at $13^{\circ} \mathrm{C}$. The temperature was then decreased $1^{\circ} \mathrm{C}$ per day until $5^{\circ} \mathrm{C}$ was reached and was maintained at this temperature for 6 weeks. After this period the temperature was increased $1^{\circ} \mathrm{C}$ per day until $12^{\circ} \mathrm{C}$ was reached and was maintained at $12^{\circ} \mathrm{C}$ for 2 weeks. The temperature was raised in a similar manner to $18^{\circ} \mathrm{C}$ and then $24^{\circ} \mathrm{C}$ and was maintained at each of these temperatures for 2 weeks. Temperatures of $5^{\circ} \mathrm{C}$ to $24^{\circ} \mathrm{C}$ are the usual range to which juvenile summer flounder are exposed in the lower Chesapeake Bay region (Burreson and Zwerner, 1982). 
Individuals in the remaining group of 20 fish (Group 3) were each injected intraperitoneally by syringe with approximately 22,750 T. bullocki in $0.1 \mathrm{ml}$ of $0.6 \%$ saline diluted flounder blood. This group was maintained at $5^{\circ} \mathrm{C}$ for the duration of the experiment, 12 weeks. An additional group of 5 flounder (Group 4) was used to sample preinfection variables at $13^{\circ} \mathrm{C}$. At the end of the holding period for each temperature of $5^{\circ} \mathrm{C}, 12^{\circ} \mathrm{C}, 18^{\circ} \mathrm{C}$ and $24^{\circ} \mathrm{C}, 7$ fish each from the infected and uninfected groups were sampled for the presence of trypanoplasms. At the same time 5 fish from the syringe innoculated group were also sampled for the same parameter. Plasma incubation tests (Barrow, 1955; Bower and Woo, 1977) were conducted on each fish to detect the presence of lysing antibodies against the trypanoplasms. Fish were discarded after sampling.

Determination of the Presence of Trypanoplasm Infections, Hematocrit and Hemoglobin Values

Blood was withdrawn from the caudal hemal arch of each fish with sterile needle and syringe and examined in a drop of $0.6 \%$ filtered saline for the presence of hemoflagellates. Intensity of infection was determined by diluting blood with $0.6 \%$ saline in a WBC pipette and counting flagellates in an improved Neubauer hemacytometer. Infections below 200 flagellates $/ \mathrm{mm}^{3}$ blood were considered light, those between 200 and 2000 flagellates/ $\mathrm{mm}^{3}$ were moderate, and those higher than 2000 flagellates $/ \mathrm{mm}^{3}$ were considered heavy. Smears made from blood or peritoneal fluid were air dried, fixed in absolute methanol for 5 minutes and stained for 30 to 45 minutes in $10 \%$ Giemsa 
blood stain (Original Azure Blend) buffered at $7.2 \mathrm{pH}$.

Microhematocrit preparations were also examined for flagellates after recording packed cell volume. Hemoglobin concentrations were determined by the cyanomethemoglobin method.

\section{In Vitro Plasma Incubation Test}

Blood from each fish was collected in sterile, heparinized evacuated blood collection tubes, stored at $4^{\circ} \mathrm{C}$, and centrifuged for 3 minutes within 24 hours. The collected plasma was immediately placed in $25 \mu 1$ quantities in microtiter plates in two-fold dilutions with $0.6 \%$ saline. The microtiter plates were then stored at $4^{\circ} \mathrm{C}$ while a live $\underline{\text { T. }}$ bullocki suspension was being prepared. Heparinized peritoneal fluid from a heavily infected summer flounder was washed in saline, centrifuged and resuspended. Twenty-five $\mu 1$ of this suspension containing approximately 100 organisms was placed in each well of the microtiter plate containing the serially diluted plasma and incubated for 3 hours at the ambient temperature of the sampled fish. Each well was examined with an inverted microscope to determine whether the flagellates lived or were lysed.

Wehnert and Woo (1980) reported that complement is involved in the lysis of trypanoplasms in fish, therefore as a control, complement was deactivated by heating plasma from fish in each group for 30 minutes at $56^{\circ} \mathrm{C}$. A solution of $0.6 \%$ saline served as an additional control. A suspension of $\underline{T}$. bullocki was incubated for 3 hours in both the heat deactivated plasma and saline as described above and then examined for active hemoflagellates. 
Determination of Total Plasma Protein

The amount of protein in each pooled plasma sample was determined by the biuret procedure. Human serum albumin and globulin was used as the reference protein.

\section{Electrophoretic Techniques}

The method of Kohn (1960) as modified by the Gelman Instrument

Co., Ann Arbor, Michigan, was used for cellulose polyacetate

electrophoresis. Three to four microliters of sera were applied to each membrane of Sepraphore III. Electrophoresis was carried out at room temperature with a current of $225 \mathrm{v}$ per strip for 25 minutes, buffered in cold $0.06 \mathrm{M}$ Tris-Barbitol-Sodium Barbitol (pH 8.8). The strips were then stained with $0.5 \%$ Ponceau $S$ in $7.5 \%$ trichloroacetic acid, dehydrated and cleared in $40 \%(\mathrm{v} / \mathrm{v})$ aqueous $\mathrm{N}$-methyl Pyrrolidone. They were then placed on glass slides and dried at $100^{\circ} \mathrm{C}$ until transparent. The bands were scanned on a Gelscan. The relative percentage of each component present on the strip was calculated from the integrator trace with a digital planimeter.

\section{Statistical Techniques}

The mean hematocrit and hemoglobin values of all the experimental fish groups 1,2 , and 3 were statistically analyzed using the Student's t-test. The values of the beta globulin component and the total globulin component of sera separated electrophoretically were statistically analyzed using the Mann-Whitney u-test. 
Field Observations

An additional 110 juvenile summer flounder were collected by otter trawl from February through June, 1982 in the lower York River and the lower Chesapeake Bay, Virginia and maintained at ambient temperatures. This approximates the period associated with the decline in prevalence of $\underline{T}$. bullocki infections in summer flounder (Burreson and Zwerner, 1982). These fish were examined within two to three days for the presence of hemoflagellates and then discarded. Plasma was collected and saved from 7 fish from each sampling period and later used for plasma incubation tests.

Another 55 adult and subadult summer flounder ( $\geq 250 \mathrm{~mm}$ ) were collected by otter traw1 during 1981 and 1982 in the lower Chesapeake Bay and off the Virginia coast. These fish were examined within 2 to 3 days for the presence of hemoflagellates and then discarded. Plasma was collected and saved from all fish from each sampling and was later used for plasma incubation tests. 
RESULTS

\section{Experimental Observations}

Hematocrit and Hemoglobin Values (See Appendix I for individual values)

Hematocrit and hemoglobin values for infected fish (Group 1 , Figure 1) declined from pre-infection values at $13^{\circ} \mathrm{C}$ through the $5^{\circ} \mathrm{C}$ and $12^{\circ} \mathrm{C}$ samplings, increased at $18^{\circ} \mathrm{C}$, declined slightly at $24^{\circ} \mathrm{C}$, and increased after an additional 4 weeks at $24^{\circ} \mathrm{C}$ to values similar to those at pre-infection. Hematocrit and hemoglobin values for uninfected fish (Group 2, Figure 1) decreased after 6 weeks at $5^{\circ} \mathrm{C}$ from pre-experimental values, followed by an increase at $12^{\circ} \mathrm{C}$, similar values at $18^{\circ} \mathrm{C}$, a decrease at $24^{\circ} \mathrm{C}$, and an increase again after an additional 4 weeks at $24^{\circ} \mathrm{C}$ to values similar to those at pre-experimental levels. Hematocrit and hemoglobin values for injected fish (Group 3, Figure 2) maintained at $5^{\circ} \mathrm{C}$ for the 12 week experiment declined steadily from pre-injection values at $13^{\circ} \mathrm{C}$ through 10 weeks at $5^{\circ} \mathrm{C}$ and then increased after 12 weeks at $5^{\circ} \mathrm{C}$. The values for the injected fish throughout the 12 weeks never attained pre-injection levels.

Hematocrit and hemoglobin values from infected flounder (Group 1) and uninfected flounder (Group 2) were significantly different at $12^{\circ} \mathrm{C}$ $(\alpha=.01)$. Hemoglobin values were significantly different at $18^{\circ} \mathrm{C}$ $(\alpha=.01)$ (Table 1$)$. Hematocrit and hemoglobin values from infected 
Figure 1. Hematological data of Trypanoplasma bullocki infected (--) and noninfected $(-)$ juvenile summer flounder. Each point represents the mean value with the range, where $N=7$, except at $13^{\circ} \mathrm{C}$ where $\mathrm{N}=5$, and at $24^{\circ} \mathrm{C} / 16$ wk where $\mathrm{N}=5$ for infected fish and $\mathrm{N}=2$ for noninfected fish. 


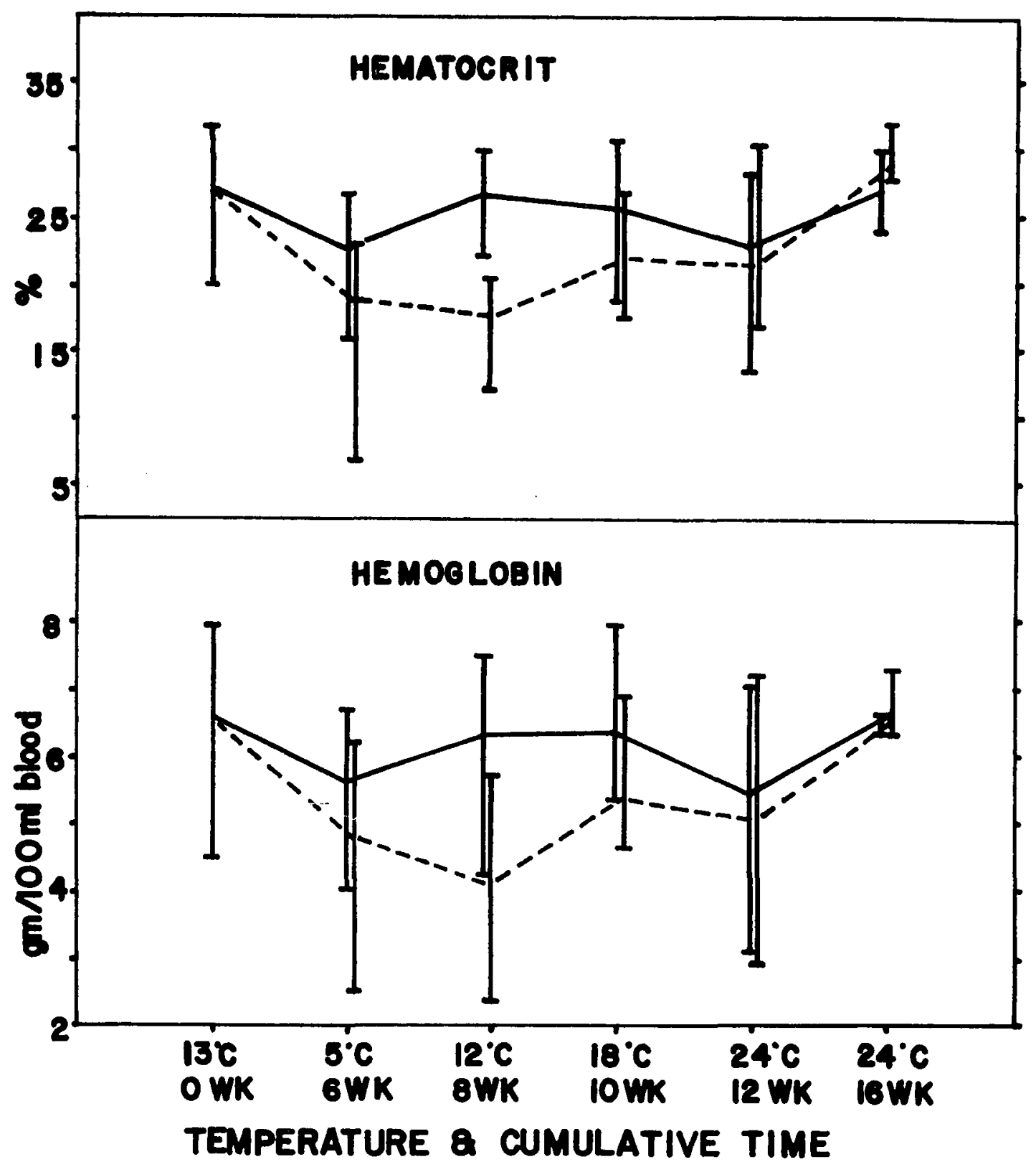


Figure 2. Hematological data of Trypanoplasma bullocki injected juvenile summer flounder maintained at $5^{\circ} \mathrm{C}$ for 12 weeks. Each point represents the mean value with the range, where $\mathrm{N}=5$. 


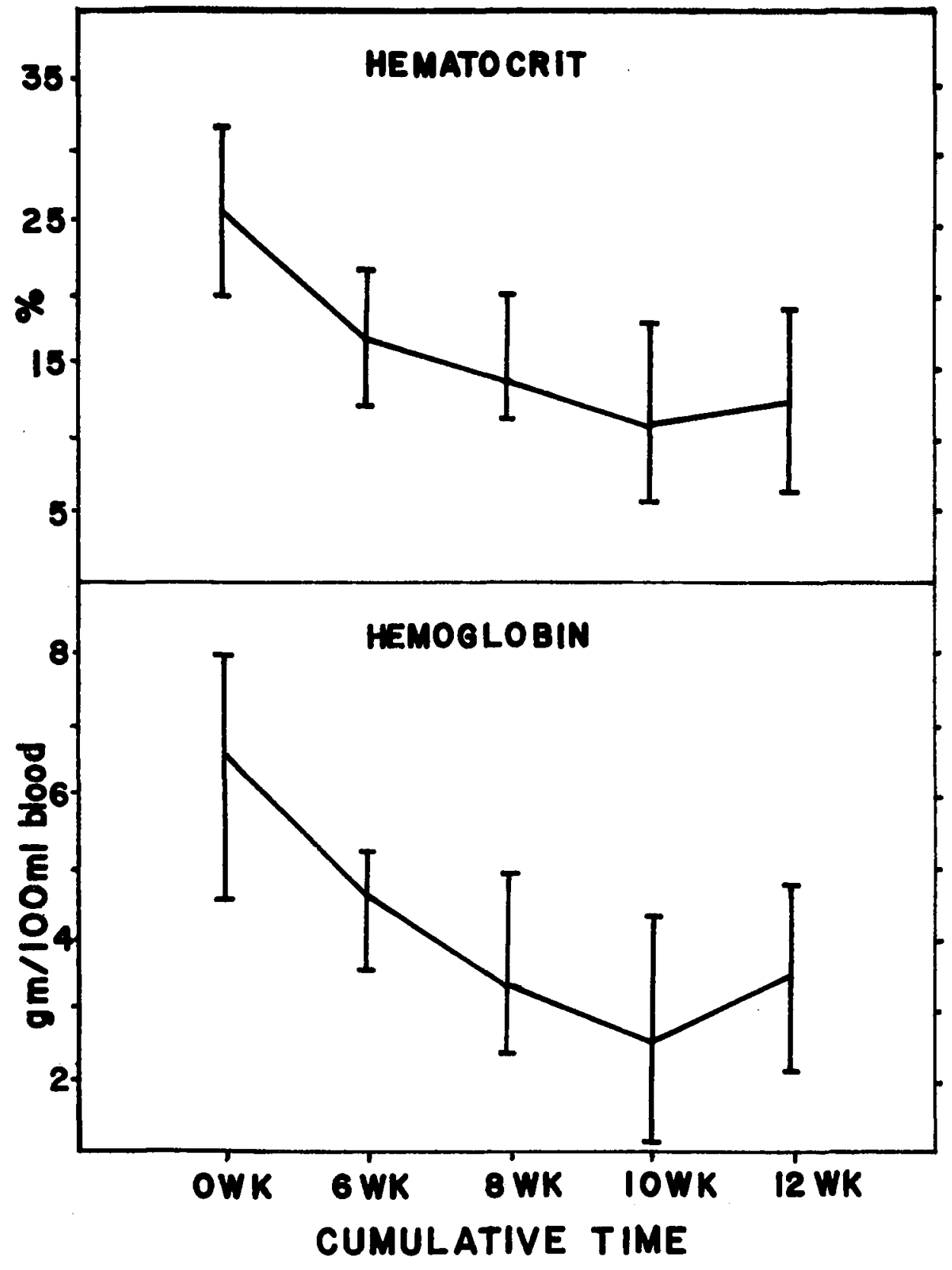


Table 1. Statistical Comparison of Blood Determinations Between Trypanoplasma bullocki Infected (Group 1) and Noninfected (Group 2) Juvenile Summer Flounder. (Data given in Figure 1).

\begin{tabular}{ccc}
\hline $\begin{array}{c}\text { Comparison of } \\
\text { means }\end{array}$ & \multicolumn{2}{c}{ student's t value } \\
\cline { 2 - 3 } Hematocrit & Hemoglobin \\
\hline $5^{\circ} \mathrm{C}$ & 2.04 & 1.72 \\
$12^{\circ} \mathrm{C}$ & $7.38 *$ & $5.41 *$ \\
$18^{\circ} \mathrm{C}$ & 2.57 & $2.76 *$ \\
$24^{\circ} \mathrm{C}$ & 0.77 & 0.57 \\
\hline
\end{tabular}

*Means are significant $1 y$ different, $t \quad 0.01=2.68$ with $12 \mathrm{df}$. 
flounder (Group 1) and injected flounder (Group 3) maintained at $5^{\circ} \mathrm{C}$ for the entire 12 week experiment were significantly different after 10 and 12 weeks $(\alpha=.05$ ) (Table 2).

Observations on the Course of Experimental Infections

(See Appendix I for individual Values)

The intensity of infection in infected fish (Group 1, Figure 3) exposed to increasing water temperatures $\left(12^{\circ} \mathrm{C}\right.$ to $\left.24^{\circ} \mathrm{C}\right)$ progressively declined and after 6 weeks at $24^{\circ} \mathrm{C}$ none of the fish were infected. The intensity of infection in injected fish maintained at $5^{\circ} \mathrm{C}$ for the entire 12 week experiment (Group 3, Figure 3) progressively increased. Uninfected fish were never observed throughout the 12 week period in this group.

In Vitro Plasma Incubation Tests

Plasma from both infected and uninfected fish (Groups 1 and 2) held at $5^{\circ} \mathrm{C}$ for 6 weeks showed no lytic activity. At $12^{\circ} \mathrm{C}$ activity was present in the uninfected group (Group 2) with lysis occurring in the plasma of all the fish sampled (Table 3). Heat inactivation of complement did not destroy the lytic activity. The plasma of infected group 1 fish did not exhibit lytic activity until a temperature of $24^{\circ} \mathrm{C}$ was reached and then only one was positive. The intensity of infection was the lowest in this fish with only 12.5 flagellates $/ \mathrm{mm}^{3}$ blood. Although all fish in group 1 were infected, as temperature increased their blood showed a steady decline in the intensity of 
Table 2. Statistical Comparison of Blood Determinations Between Trypanoplasma bullocki Infected (Group 1) and Injected (Group 3) Juvenile Summer Flounder. (Data given in Figures 1 and 2).

\begin{tabular}{|c|c|c|}
\hline \multirow{2}{*}{$\begin{array}{c}\text { Comparison of } \\
\text { means }\end{array}$} & \multicolumn{2}{|c|}{ student's $t$ value } \\
\hline & Hematocrit & Hemoglobin \\
\hline 8 weeks & 1.81 & 1.32 \\
\hline 10 weeks & $1.89 *$ & $4.79 *$ \\
\hline 12 weeks & $3.07 * *$ & $1.92 * *$ \\
\hline $\begin{array}{l}\text { * Means are } \\
\text { with } 10 \mathrm{df}\end{array}$ & significantly different, & , $t 0.05=1.81$ \\
\hline $\begin{array}{l}\text { ** Means are } \\
\text { with } 9 \text { df. }\end{array}$ & significantly different, & $t 0.05=1.83$ \\
\hline
\end{tabular}


Figure 3. Course of Trypanoplasma bullocki infections in juvenile summer flounder maintained at elevating water temperatures and at a constant $5^{\circ} \mathrm{C}$, where $U=$ Uninfected, L=Light, M=Moderate, H=Heavy. 

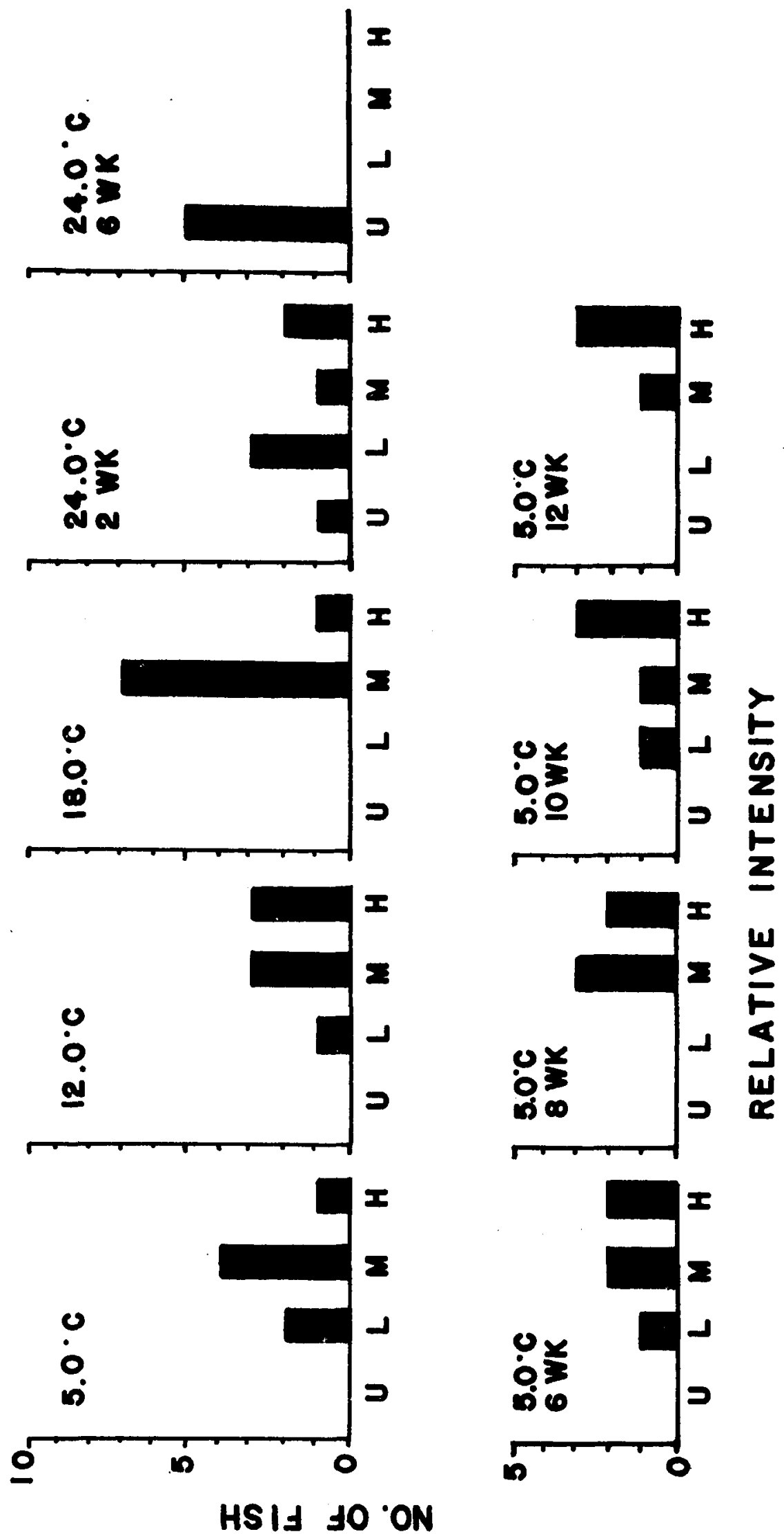
Table 3. Trypanoplasma bullocki Incubated In Vitro with Plasma from Juvenile Summer Flounder, Paralichthys dentatus, from experimental infections.

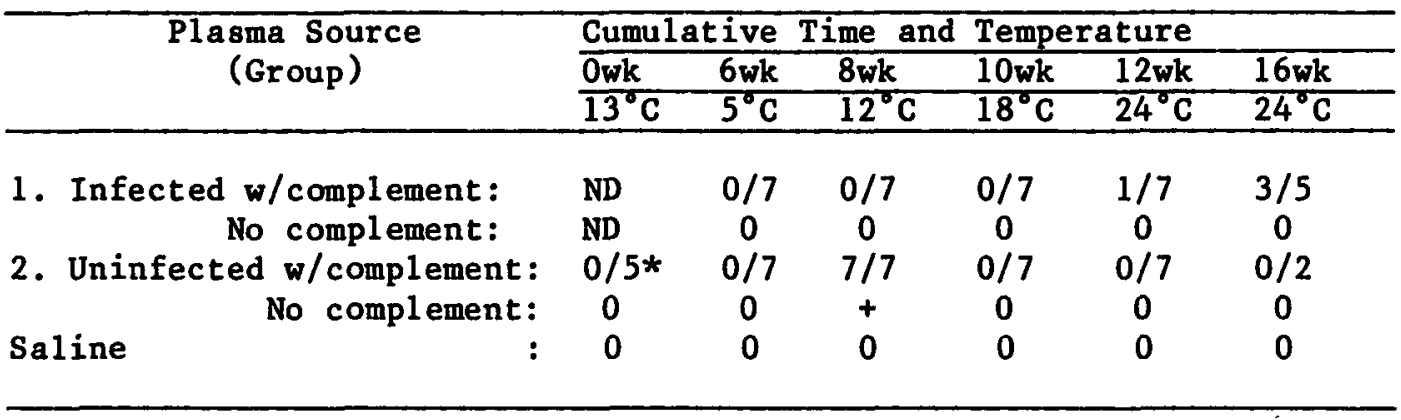

\begin{tabular}{|c|c|c|c|c|c|c|c|}
\hline Plasma Source & & Cum & ative & Time, & Tempe: & ture & $5^{\circ} \mathrm{C}$ \\
\hline (Group) & & $\overline{0 w k}$ & 6wk & $8 w k$ & $10 \mathrm{wk}$ & $12 \mathrm{wk}$ & \\
\hline $\begin{array}{l}\text { 3. w/complement } \\
\text { No compl ement }\end{array}$ & : & $\begin{array}{l}\text { ND } \\
\text { ND }\end{array}$ & $\begin{array}{c}0 / 5 \\
0\end{array}$ & $\begin{array}{c}0 / 5 \\
0\end{array}$ & $\begin{array}{c}0 / 5 \\
0\end{array}$ & $\begin{array}{c}0 / 5 \\
0\end{array}$ & \\
\hline
\end{tabular}

*No. Positive Lytic Reactions/No. Incubated $\mathrm{ND}=$ Not Done, $0=$ No Lysis, +=Lysis 
infection and at $24^{\circ} \mathrm{C}$, one flounder was no longer infected (or at least no flagellates could be found in the blood).

The experiment was originally designed to be terminated after 2 weeks at $24^{\circ} \mathrm{C}$. However, since plasma lysis activity was present in at least 1 of the infected group 1 fish at $24^{\circ} \mathrm{C}$ it was decided to maintain the remaining flounder at this temperature for an additional 4 weeks. After this time trypanoplasmacidal lysis was observed in 3 out of 5 fish sampled from this group (Table 3), and none of the fish were infected. Titers ranged from 1:16 to greater than 1:64.

The plasma of flounder in group 3 kept at $5^{\circ} \mathrm{C}$ for the entire 12 week experiment, never displayed lytic activity (Table 3). As time progressed the number of trypanoplasms present in the blood steadily increased with levels ranging from 1475 to 4137.5 flagellates $/ \mathrm{mm}^{3}$ blood at the final sampling. The increase in intensity was accompanined by increasing edema of the peritoneal cavity and by the 12 th week fish began to die. Edems was never apparent in infected group 1 fish maintained at temperatures of $12^{\circ} \mathrm{C}$ and above. The peritoneal fluid of fish kept at $5^{\circ} \mathrm{C}$ contained trypanoplasms, erythrocytes, leukocytes, and in particular macrophages with engulfed trypanoplasms (Fig. 4). Plasma samples taken from the uninfected group 4 flounder at $13^{\circ} \mathrm{C}$ showed no trypanoplasmacidal lysis activity (Table 3).

In all cases the heat deactivated plasma and saline controls showed no lytic activity, except the uninfected group 2 fish maintained at $12^{\circ} \mathrm{C}$, as previously mentioned (Table 3 ). 
Figure 4. Peritoneal fluid smear from juvenile flounder held at $5^{\circ} \mathrm{C}$ showing both free and phagocytized T. bullocki. Giemsa stain, $X 3000$. $K=K$ inetoplast, M=Macrophage, $N=F$ lagellate Nucleus. 


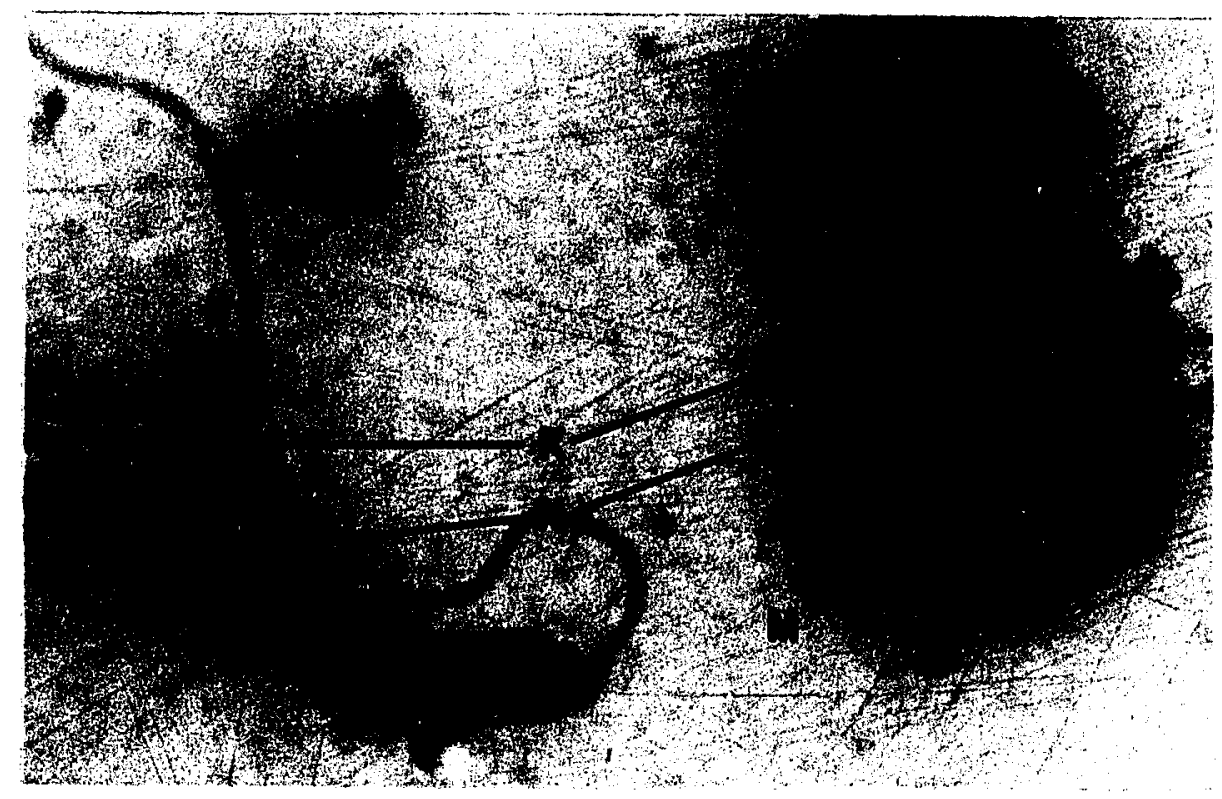


Serum Protein Patterns

(See Appendix II for individual values)

Electrophoretic analysis of pooled sera from juvenile flounder produced a pattern showing 7 protein components (Figures 5-8)

consisting of a prealbumin and albumin complex peak, an alpha-1 peak, 3 globulin peaks analagous to alpha-2, beta-1 and beta-2 fractions, and a complex of gamma peaks. Protein values determined by electrophoretic separation of infected flounder sera from $24^{\circ} \mathrm{C}$ (Group 1 after 6 weeks at this temperature) (Table 4) revealed a significant increase in the globulin fraction $(\alpha=0.05)$ (Table 5), in particular the beta globulin components $(\alpha=0.05)$, when compared to infected fish at $5^{\circ} \mathrm{C}$ (Group 1). Although values were higher for the beta globulin components of infected fish at $24^{\circ} \mathrm{C}$ (Group 1) (Table 4) compared to uninfected fish at this temperature (Group 2), they were not statistically significant $(\alpha=0.05)$ (Table 5$)$, however the values for the total globulin component, in comparison, were significantly higher $(\alpha=0.05)$.

\section{Field Observations}

As water temperatures increased during the spring, a steady decline in the number of infected juvenile summer flounder occurred as well as a decrease in the intensity of infection (Fig. 9). There was a fairly even ratio of uninfected to infected fish in March when water temperatures were $6.0^{\circ} \mathrm{C}$ (Fig. 9b), while in May with water temperatures between $14^{\circ} \mathrm{C}$ and $18^{\circ} \mathrm{C}$ there were more uninfected 
Figure 5. Electrophoretograms of human serum (--) and juvenile infected surmer flounder serum $(-)$ separated on cellulose polyacetate. 


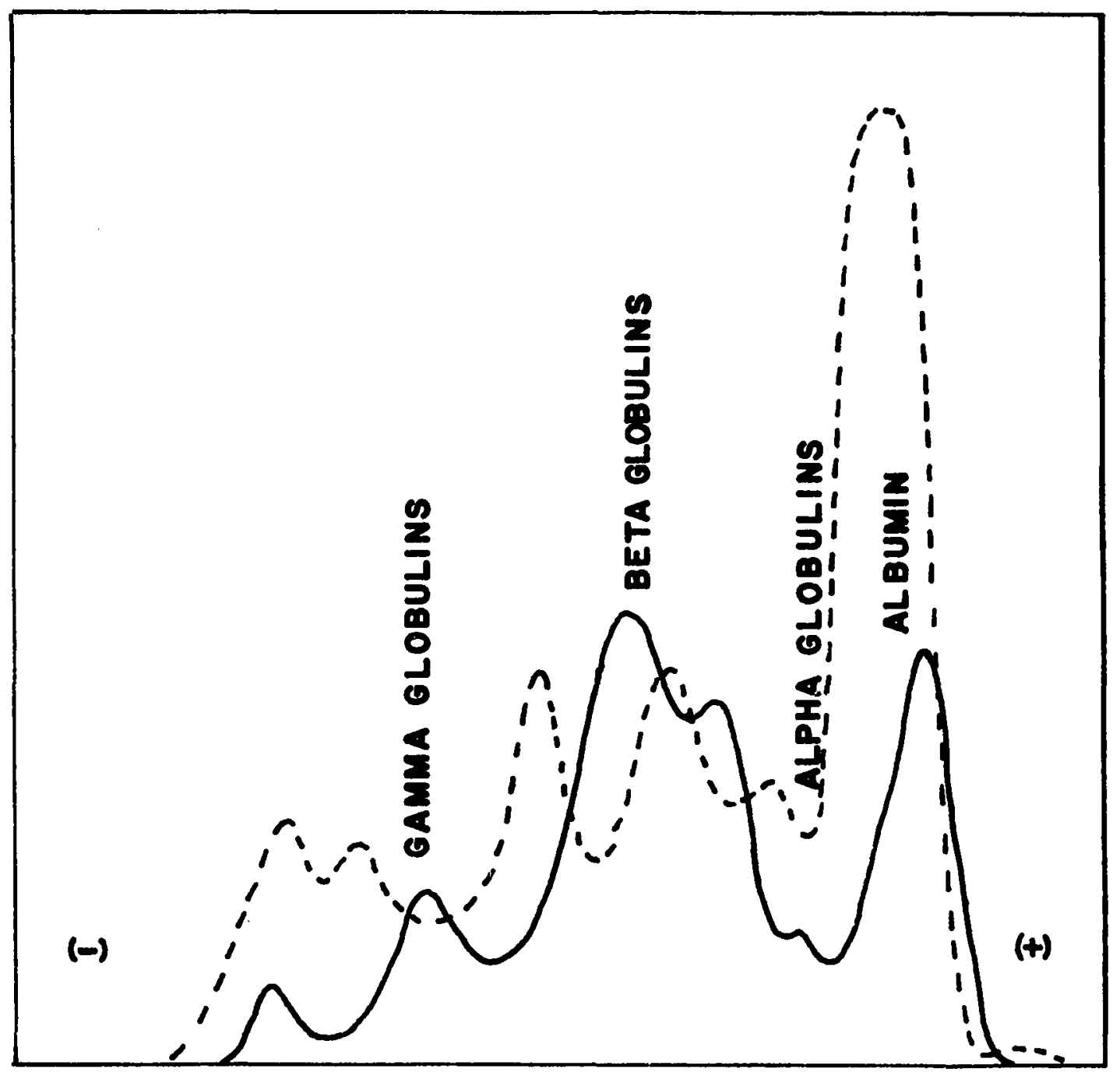


Figure 6. Electrophoretograms of sera from 4 juvenile summer flounder infected with Trypanoplasma bullocki at $5^{\circ} \mathrm{C}$. 


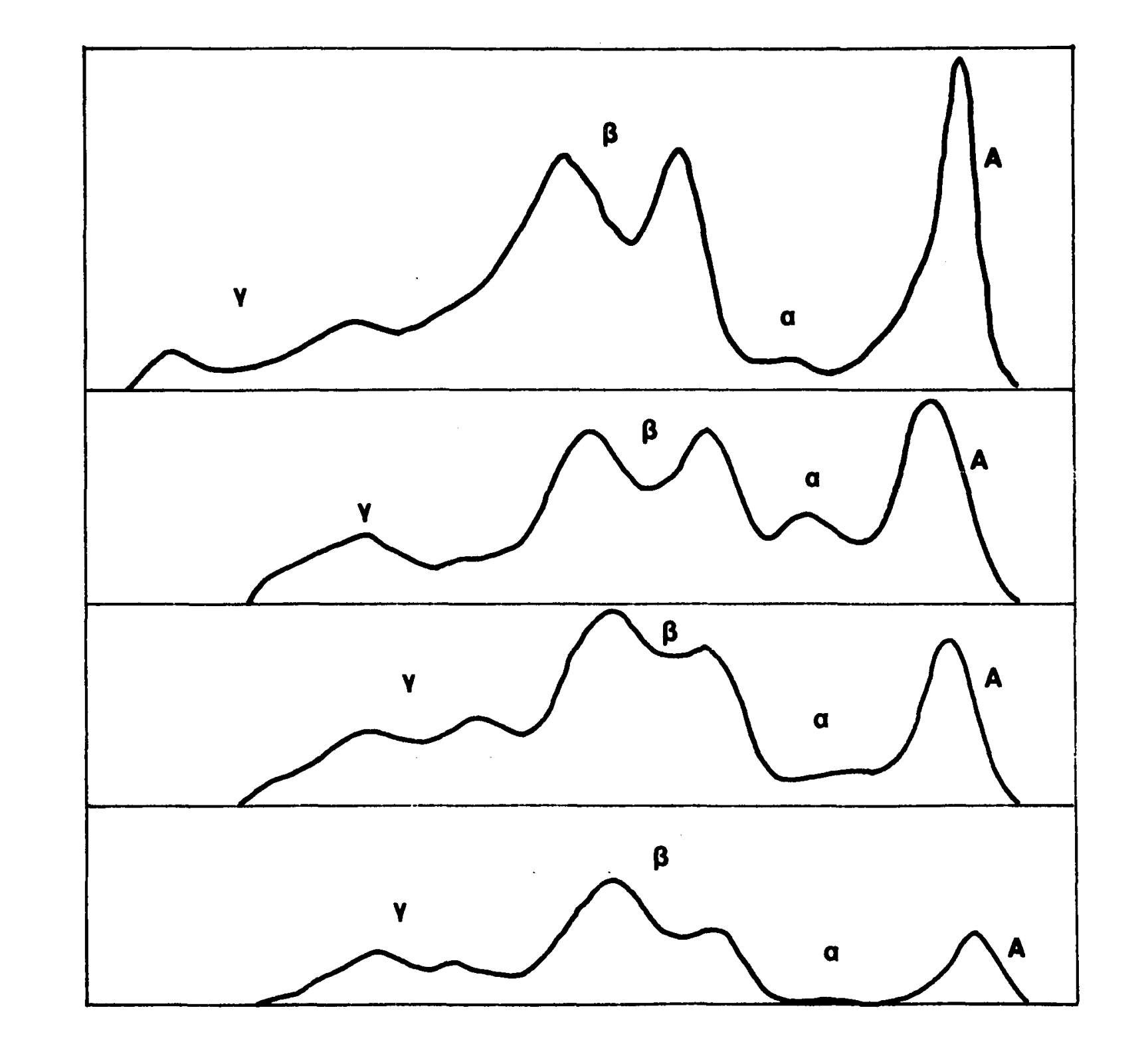


Figure 7. Electrophoretograms of sera from 6 noninfected juvenile summer flounder at $24^{\circ} \mathrm{C}$. 


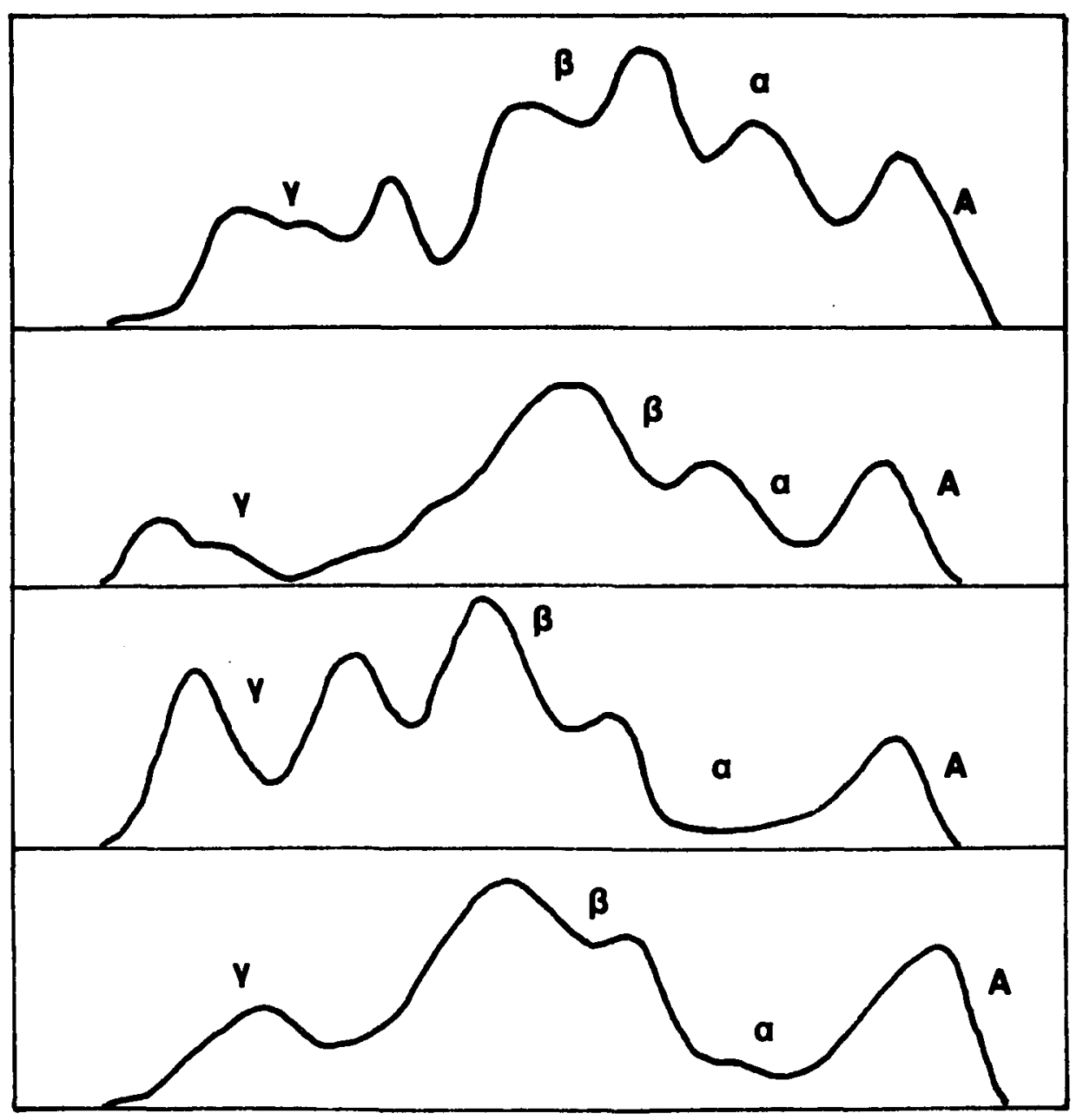




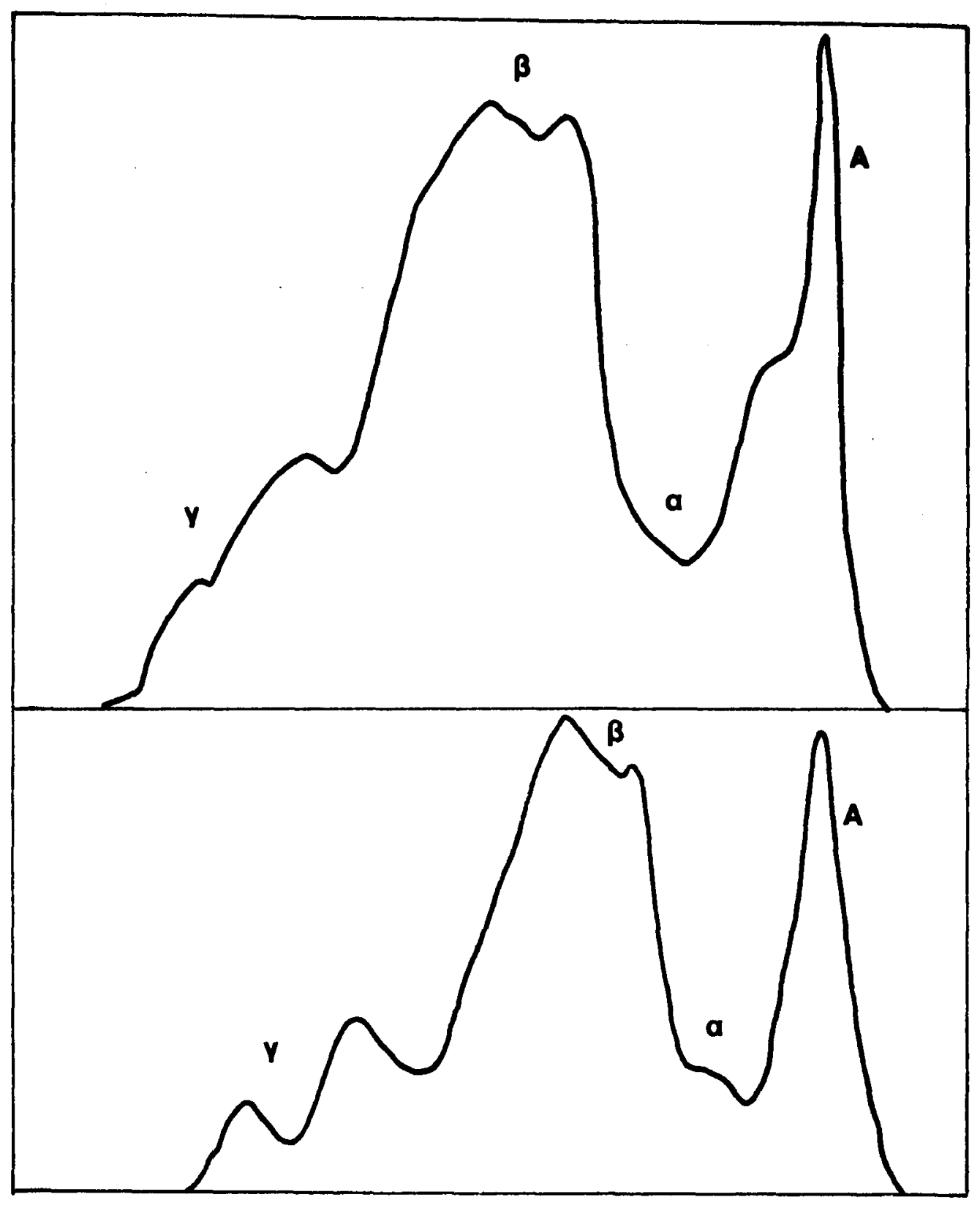


Figure 8. Electrophoretograms of sera from 5 juvenile summer flounder infected with Trypanoplasma bullocki at $24^{\circ} \mathrm{C}$. 


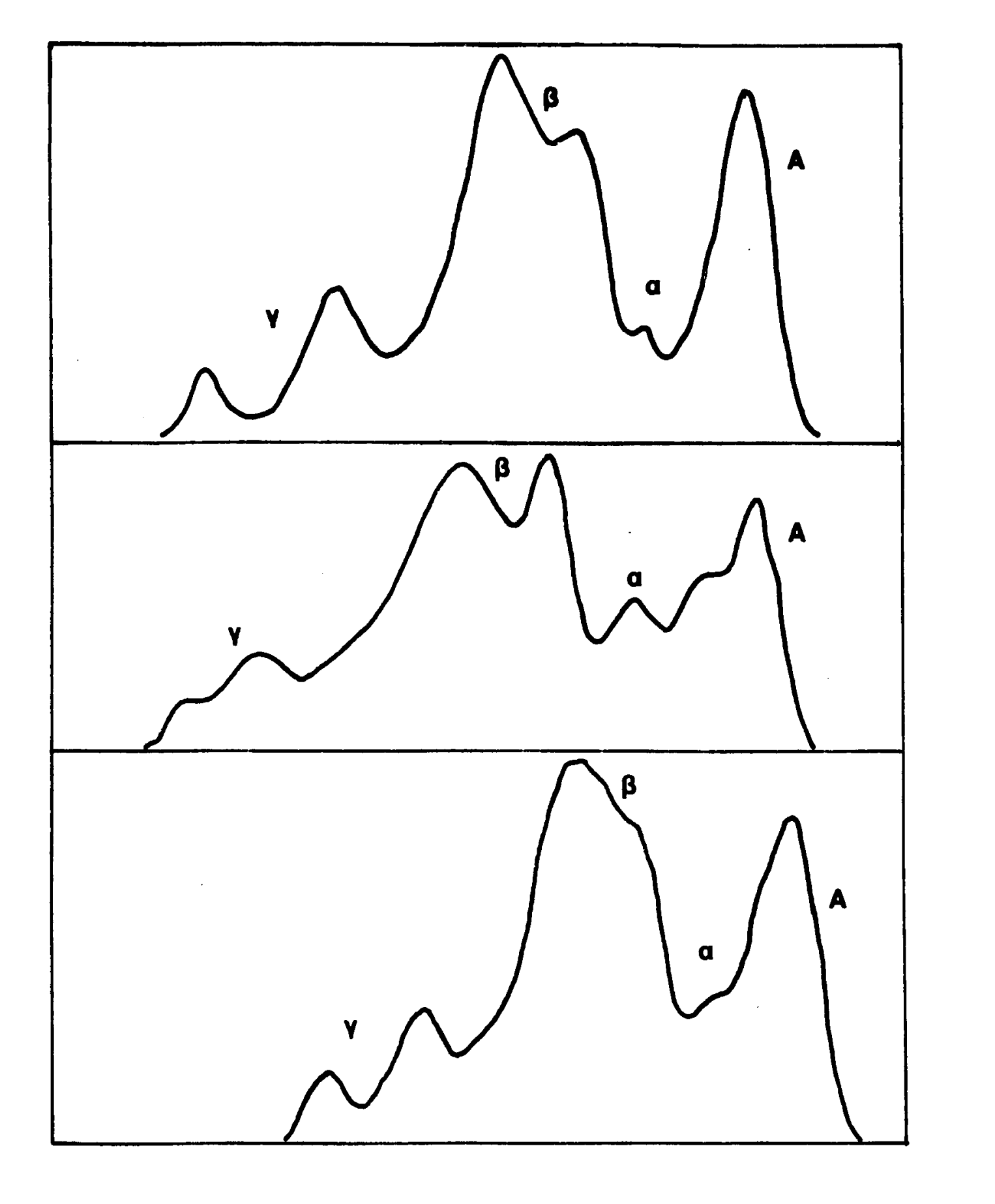




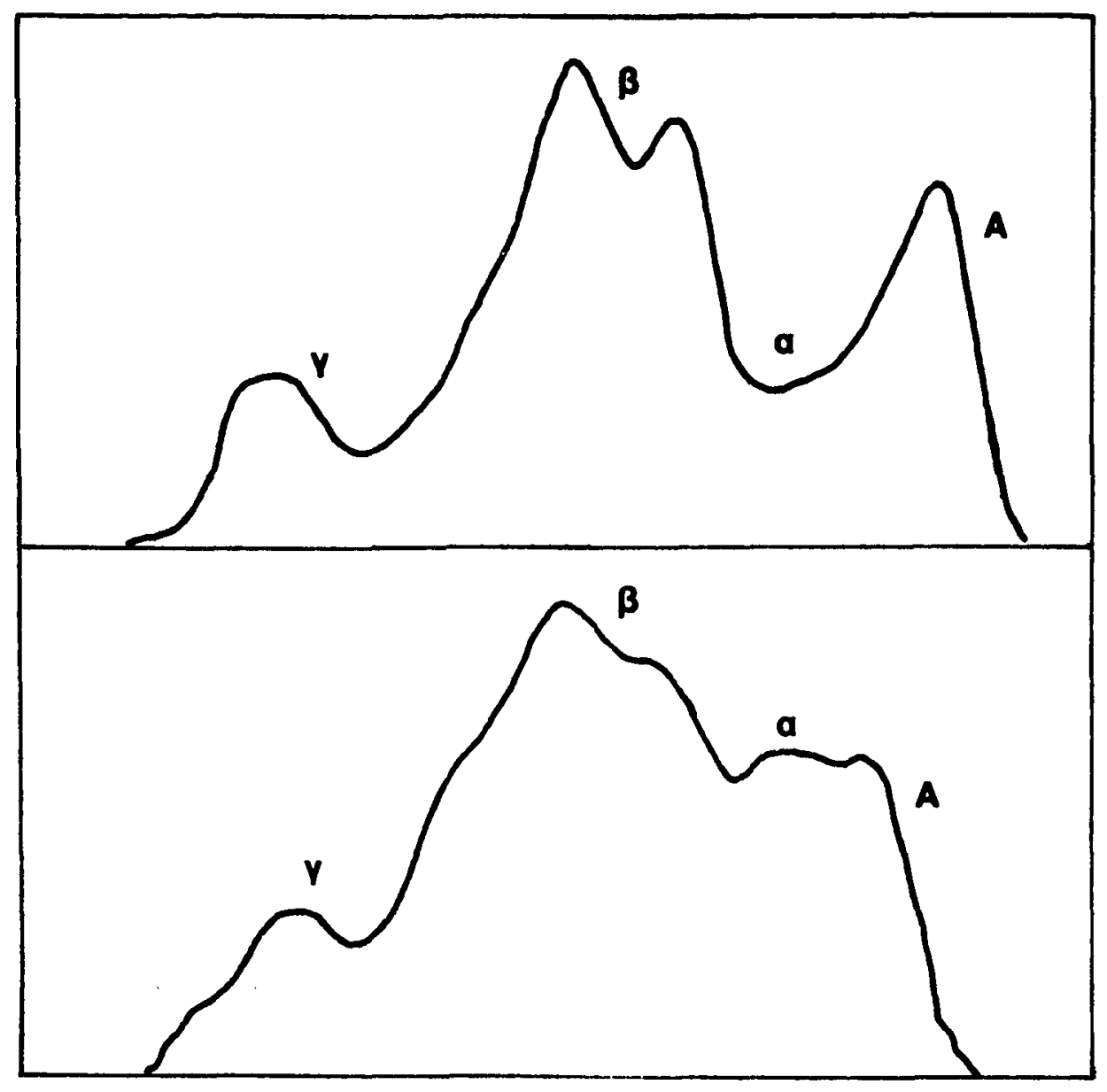




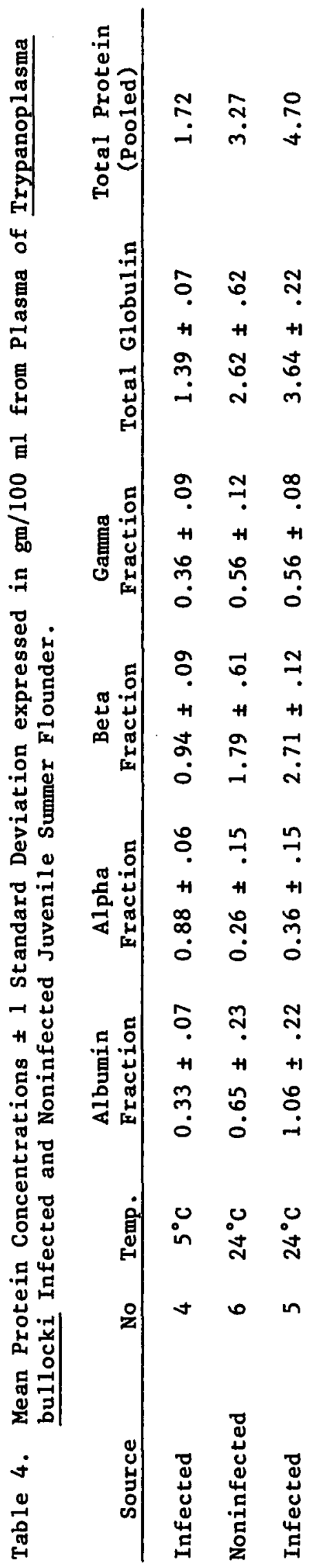


Table 5. Statistical Comparison of Protein Determinations among Trypanoplasma bullocki Infected and Noninfected Juvenile Summer Flounder.

\begin{tabular}{cccc}
\hline $\begin{array}{c}\text { Comparison of } \\
\text { values }\end{array}$ & \multicolumn{2}{c}{ B values } \\
\hline $5^{\circ} \mathrm{C}$ Infected: & $24^{\circ} \mathrm{C}$ Infected & $0 *$ & $0 *$ \\
$24^{\circ} \mathrm{C}$ Infected: & $24^{\circ} \mathrm{C}$ Noninfected & 3.5 & $2.0 * *$ \\
\hline
\end{tabular}

* Values are significantly different, $u$ 0.05=1.0 with $n_{1}=4, n_{2}=5$

** Values are significantly different, u $0.05=3.0$ with $n_{1}=5, n_{2}=6$ 
Figure 9. Intensity of T. bullocki infections in samples of juvenile flounder taken from the lower Chesapeake Bay during the spring of 1982. U=Uninfected, L=Light, M=Moderate, $\mathrm{H}=$ Heavy . 


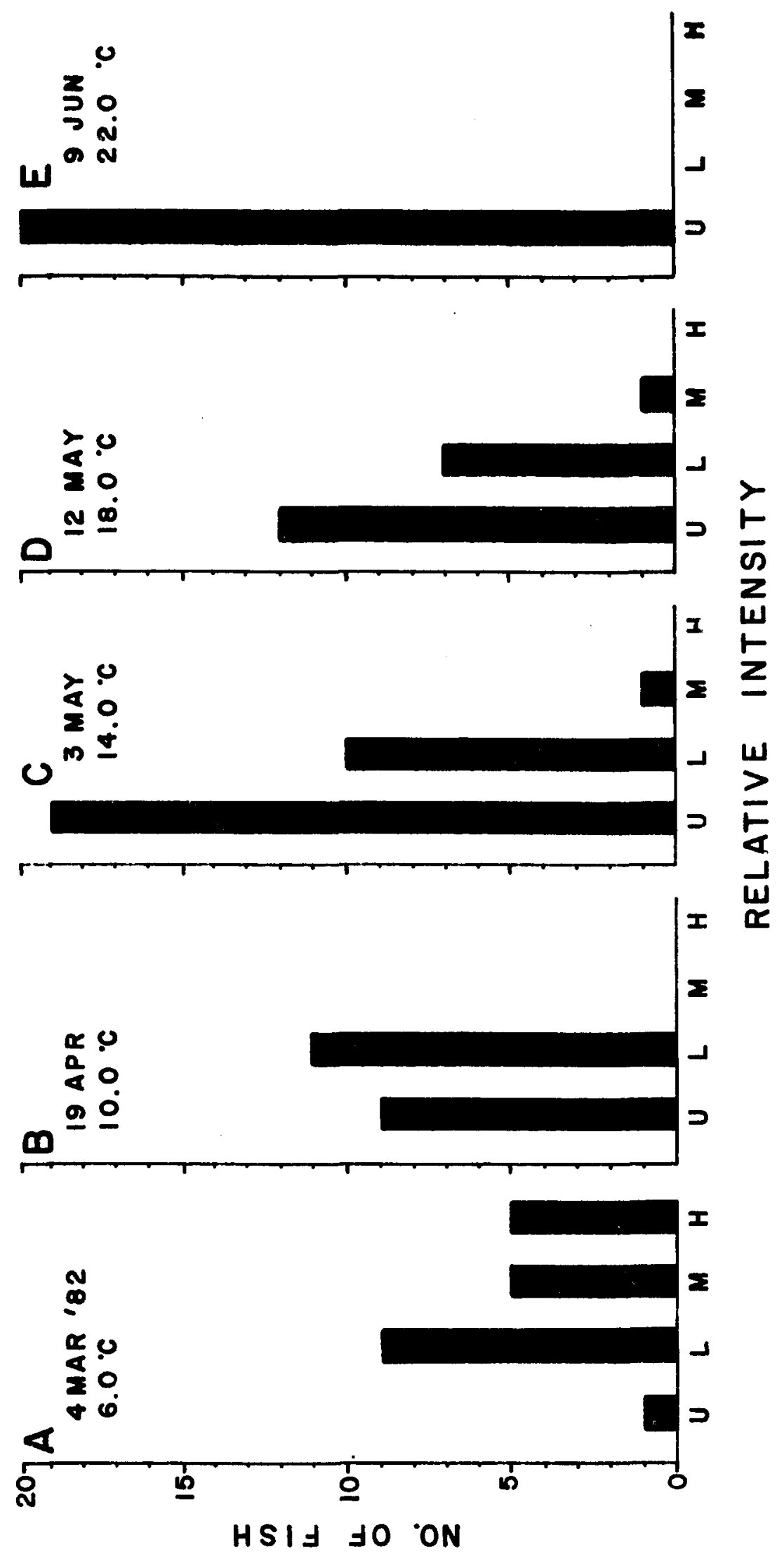


individuals than infected ones (Figs. $9 \mathrm{c}$ and d). In June at $22^{\circ} \mathrm{C}$ all fish examined were uninfected (Fig 9e).

Plasma incubation tests with 7 fish taken prior to March revealed no lytic activity. These fish were either moderately or heavily parasitized with I. bullocki. Plasma taken from fish in April and thereafter displayed trypanoplasmacidal lysis in all fish which were

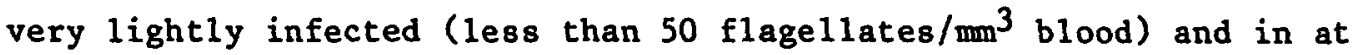
least $50 \%$ of the uninfected fish examined (Table 6). Titers ranged from $1: 8$ to $1: 64$. In all cases heat deactivated plasma and saline controls showed no lytic activity (Table 6).

Plasma incubation tests with plasma from 55 uninfected adult and subadult sumner flounder taken throughout the year from the lower Chesapeake Bay and the Mid-Atlantic Bight (Table 7) revealed no lytic activity at any time in any of the plasma samples. 
TABLE 6. Trypanoplasma bullocki Incubated In Vitro with Plasma from Juvenile Summer Flounder, Paralichthys dentatus, taken from the Lower Chesapeake Bay.

\begin{tabular}{lcccccc}
\hline Plasma Source & \multicolumn{5}{c}{ Month and Temperature } \\
\cline { 2 - 6 } & FEB & APR & MAY & MAY & JUN \\
\cline { 2 - 6 } & $5^{\circ} \mathrm{C}$ & $10^{\circ} \mathrm{C}$ & $14^{\circ} \mathrm{C}$ & $18^{\circ} \mathrm{C}$ & $22^{\circ} \mathrm{C}$ \\
\hline \multirow{2}{*}{ w/complement: } & $0 / 7 *$ & $8 / 14$ & $8 / 14$ & $8 / 14$ & $4 / 7$ \\
No complement: & 0 & 0 & 0 & 0 & 0 \\
Saline & 0 & 0 & 0 & 0 & 0 \\
& & & & & & \\
\hline
\end{tabular}

*No. Positive Lytic Reactions/No. Incubated $0=$ No Lysis 
Table 7. Noninfected Subadult and Adult Summer Flounder taken from the Lower Chesapeake Bay and Mid-Atlantic Bight displaying No Trypanoplasmacidal Titers.

\begin{tabular}{rrr}
\hline Date & $\begin{array}{c}\text { Length } \\
\text { mm }\end{array}$ \\
\hline 8 & Jun & 606 \\
8 & Jun & 260 \\
8 & Jun & 380 \\
8 & Jun & 415 \\
8 & Jun & 354 \\
8 & Jun & 430 \\
8 & Jun & 485 \\
8 & Jun & 397 \\
8 & Jun & 370 \\
8 & Jun & 406 \\
8 & Jun & 402 \\
8 & Jun & 400 \\
17 & Jun & 249 \\
17 & Jun & 385 \\
17 & Jun & 335 \\
17 & Jun & 260 \\
17 & Jun & 247 \\
17 & Jun & 372 \\
17 & Jun & 420 \\
21 & Ju1 & 267 \\
21 & Ju1 & 270 \\
21 & Ju1 & 340 \\
21 & Ju1 & 317 \\
21 & Jul & 397 \\
21 & Jul & 297 \\
21 & Jul & 243 \\
21 & Jul & 352 \\
4 & Aug & 256 \\
8 & & \\
\hline
\end{tabular}

\begin{tabular}{cc}
\hline Date & $\begin{array}{c}\text { Length } \\
\text { mm }\end{array}$ \\
\hline & \\
4 Aug & 363 \\
4 Aug & 239 \\
14 Aug & 356 \\
14 Aug & 305 \\
14 Aug & 353 \\
14 Aug & 296 \\
14 Aug & 287 \\
14 Aug & 363 \\
14 Aug & 437 \\
25 Aug & 294 \\
25 Aug & 270 \\
25 Aug & 456 \\
25 Aug & 281 \\
25 Aug & 284 \\
25 Aug & 305 \\
25 Aug & 250 \\
20 Mar & 285 \\
20 Mar & 425 \\
20 Mar & 440 \\
21 Mar & 285 \\
22 Mar & 345 \\
23 Mar & 231 \\
23 Mar & 242 \\
23 Mar & 286 \\
24 Mar & 380 \\
24 Mar & 530 \\
25 Mar & 470 \\
&
\end{tabular}




\section{DISCUSSION}

From both experimental and field data it is apparent that temperature is a factor in regulating the host's immune system against trypanoplasm infections in juvenile summer flounder. Increasing trypanoplasmacidal lysis activity with elevated water temperatures indicates that the flounder's humoral immunity is responsible for the spring decline in prevalence and eventual elimination of $\underline{T}$. bullocki infections.

Lytic activity, however, was not always observed in fish that were no longer infected; in particular, in infected group 1 flounder after 6 weeks at $24^{\circ} \mathrm{C}$ compared to those held for only 2 weeks at $24^{\circ} \mathrm{C}$. In the latter group, 6 out of 7 fish were still infected, and the plasma of 1 fish exhibited lytic activity. In the first group, held for an additional 4 weeks, lytic activity was observed in only 3 of 5 fish examined, although no trypanoplasms could be found in their blood. Absence of lytic activity in 2 of the fish suggests that the period of activity is of comparative short duration, perhaps on the order of 2 to 3 weeks at this temperature. Consequently, fish displaying lytic activity at low temperatures, for example natural infections sampled at $10^{\circ} \mathrm{C}$ to $14^{\circ} \mathrm{C}$, would not display activity at higher temperatures, e.g. $18^{\circ} \mathrm{C}$ to $22^{\circ} \mathrm{C}$, if the infection had been eliminated. This is further supported by the fact that subadult and adult flounder collected in the lower Chesapeake Bay and off the Virginia coast never possessed any lytic activity against the 
trypanoplasms, even during periods when activity was observed in juveniles or in the summer when water temperatures were above $22^{\circ} \mathrm{C}$. Barrow (1955) similarly found with fish trypanosomes that lytic activity was lost sometime after the disappearance of the flagellates from the blood, and thus resembled a sterile immune mechanism.

In addition, differences between the temperature at which initial lysis was observed in natural infections $\left(10^{\circ} \mathrm{C}\right)$ and in experimental infections $\left(24^{\circ} \mathrm{C}\right)$, may be partially due to the greater rate increase in temperature to which the experimental fish were subjected. The experimental temperature increase from $5^{\circ} \mathrm{C}$ to $12^{\circ} \mathrm{C}$, was accomplished in 2 to 3 weeks, while in the Chesapeake Bay it occurred over approximately 2 months. Therefore, whereas temperatures in the experiment were adequate for a humoral response to develop, there was probably insufficient time for it to occur during the duration of the experiment. This delay is further compounded by the time lag effect at lower temperatures, $10^{\circ} \mathrm{C}$ to $15^{\circ} \mathrm{C}$ and below, where an extended latent period occurs before a primary immune response is apparent. At higher temperatures, $20^{\circ} \mathrm{C}$ to $30^{\circ} \mathrm{C}$, antibody is produced at higher kinetic rates (Trump and Hildeman, 1970; Rijkers et al., 1980 a,b; 0'Neill, 1980).

Naturally infected fish were still present at water temperatures of $18^{\circ} \mathrm{C}$, indicating that individual flounder vary in their ability to recover from trypanoplasm infections at temperatures from $10^{\circ} \mathrm{C}$ to $22^{\circ} \mathrm{C}$. This range of variability may be a result of inherent differences within summer flounder populations (Stolen et al., 1982; 
Robohm et al., 1979; Robohm and Sparrows, 1981) and/or the magnitude of the initial innoculum of hemoflagellates (Woo, 1981). Further, the observation of lytic activity at $10^{\circ} \mathrm{C}$ in naturally infected fish indicates that antibody production and secretion in flounder can occur in vivo at temperatures as low as $10^{\circ} \mathrm{C}$. In spite of the presence of antibodies at this temperature, it may take long periods before a protective effect is attained in an individual depending again on inherent variables, intensity of infection, the environment, and in particular, as in the case of experimental infections, the duration of exposure to a certain temperature regime.

The unexpected lytic activity observed in fish from uninfected group 2 flounder held at $12^{\circ} \mathrm{C}$ may have been the result of nonspecific agglutinins or lectins present in the plasma, since heat deactivation of complement did not inactivate the lytic activity.

Studies of $\underline{T}$. catostomi and $\underline{T}$. salmositica in freshwater teleosts (Bower and Woo, 1977; Wehnert and Woo, 1980) show a similar range of lysing titers with freshly collected plasma, i.e. 1:4 to $1: 32$, as we observed in both experimental and natural infections in juvenile flounder. According to Woo (1981) antibody/complement mediated lysis appears to be the major mechanism of acquired resistance against new hemoflagellate infections, and phagocytosis plays a lesser role.

The cellular component of the flounder's immune system however, appears to have a relatively more important role than the humoral response at temperatures below $12^{\circ} \mathrm{C}$ since group 3 fish began to develop ascites with large numbers of phagocytic cells in the fluid. 
At temperatures between $5^{\circ} \mathrm{C}$ and $10^{\circ} \mathrm{C}$ large numbers of monocytes and macrophages were present in ascites fluid with phagocytized tryapanoplasms. Group 3 fish kept at $5^{\circ} \mathrm{C}$ never displayed trypanoplasmacidal lysis activity during the 12 weeks he1d. This suggests that cellular defense in flounder is an important immune mechanism when temperatures do not favor the development of an effective humoral response (Rijkers et al., 1980 a,b). Similar macrophage activity was observed in $\stackrel{m}{=}$ salmositica infections of rainbow trout by Woo (1979).

Electrophoresis of sera taken from juvenile flounder (Group 1 at $24^{\circ} \mathrm{C}$ ) recovering from $\underline{T}$. bullocki infections revealed elevated globulin levels compared to those taken from infected fish at $5^{\circ} \mathrm{C}$ (Group 1) and non infected fish at $24^{\circ} \mathrm{C}$ (Group 2). In particular, beta globulin levels were significantly higher than those of infected fish at $5^{\circ} \mathrm{C}$. The immunoglobulins of marine flatfish (Baldo and Fletcher, 1973; Cottrel1, 1977a, b), as well as those of other teleosts (Evelyn, 1971; Heartwel1, 1975; Ingram and Alexander, 1976, 1977; Busch, 1978), have been shown to possess beta electrophoretic mobility. Considering this evidence, sera from recovering flounder should show concommitant increases in the globulin region, especially the beta fraction. This increase may be associated with the trypanoplasmacidal lysis activity observed in the plasma of recovering fish, and supports the hypothesis of enhanced antibody production as a result of elevated temperatures. Higher levels perhaps may not have been observed because of the short duration of lysis activity, 2 to 3 
weeks (Barrow, 1955; Sakai, 1982) and because the fish examined no longer possessed any flagellates in their blood.

Increasing trypanoplasm numbers in the blood was correlated with low hematocrit and hemoglobin levels. This was particularly significant with infected flounder (Group 3) maintained at $5^{\circ} \mathrm{C}$ for 12 weeks. Infected flounder (Group 1) exposed to elevating temperatures however, attained hemoglobin and hematocrit values similar to uninfected fish upon the termination of the experiment at $24^{\circ} \mathrm{C}$. This suggests that group 1 flounder were recovering from their infections as a result of the enhanced immunological competence associated with elevated temperatures and upon elimination of $\underline{T}$. bullocki infections the blood parameter values returned to normal. Similar depressions in blood values have been observed in Salmo gairdneri with $\underline{T}$. salmositica by Woo (1979) and Lowe-Jinde (1979).

The relationships between temperature and humoral response agree with observations made in studies on summer flounder by Stolen and coworkers (1982) where an ambient temperature of $17^{\circ} \mathrm{C}$ markedly enhanced antibody production and temperatures below $11^{\circ} \mathrm{C}$ did not. These relationships also support the hypotheses of Barrow $(1954,1955)$ and Cottrell (1977a), that decreases in the number of fish harboring hemoflagellate infections in the summer months may have resulted from increased immunological competence of fish subjected to elevated temperatures. In conclusion, increasing spring water temperatures directly enhance the immune response of juvenile summer flounder and play an important role in the elimination of $\underline{T}$. bullocki infections. 


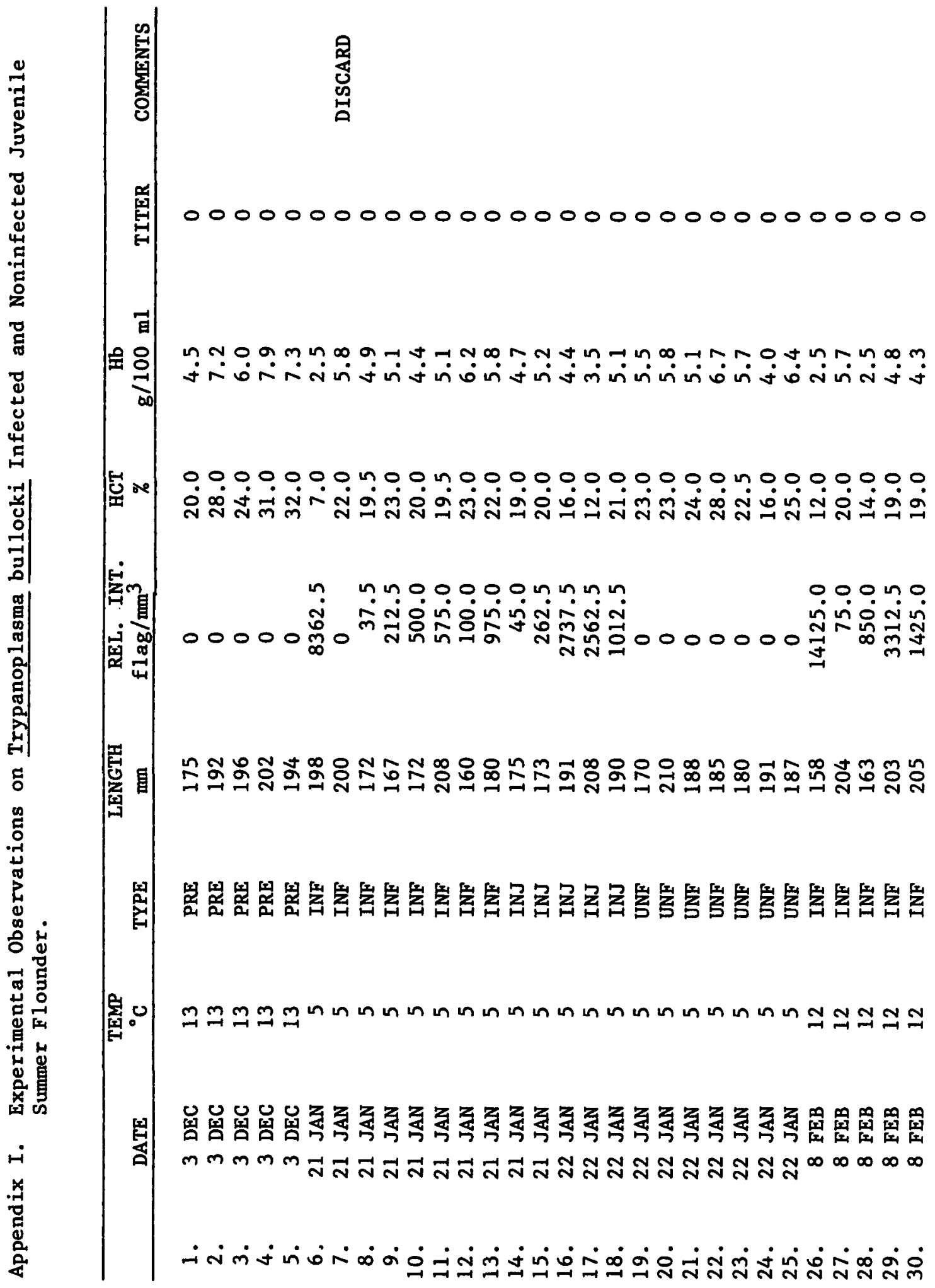




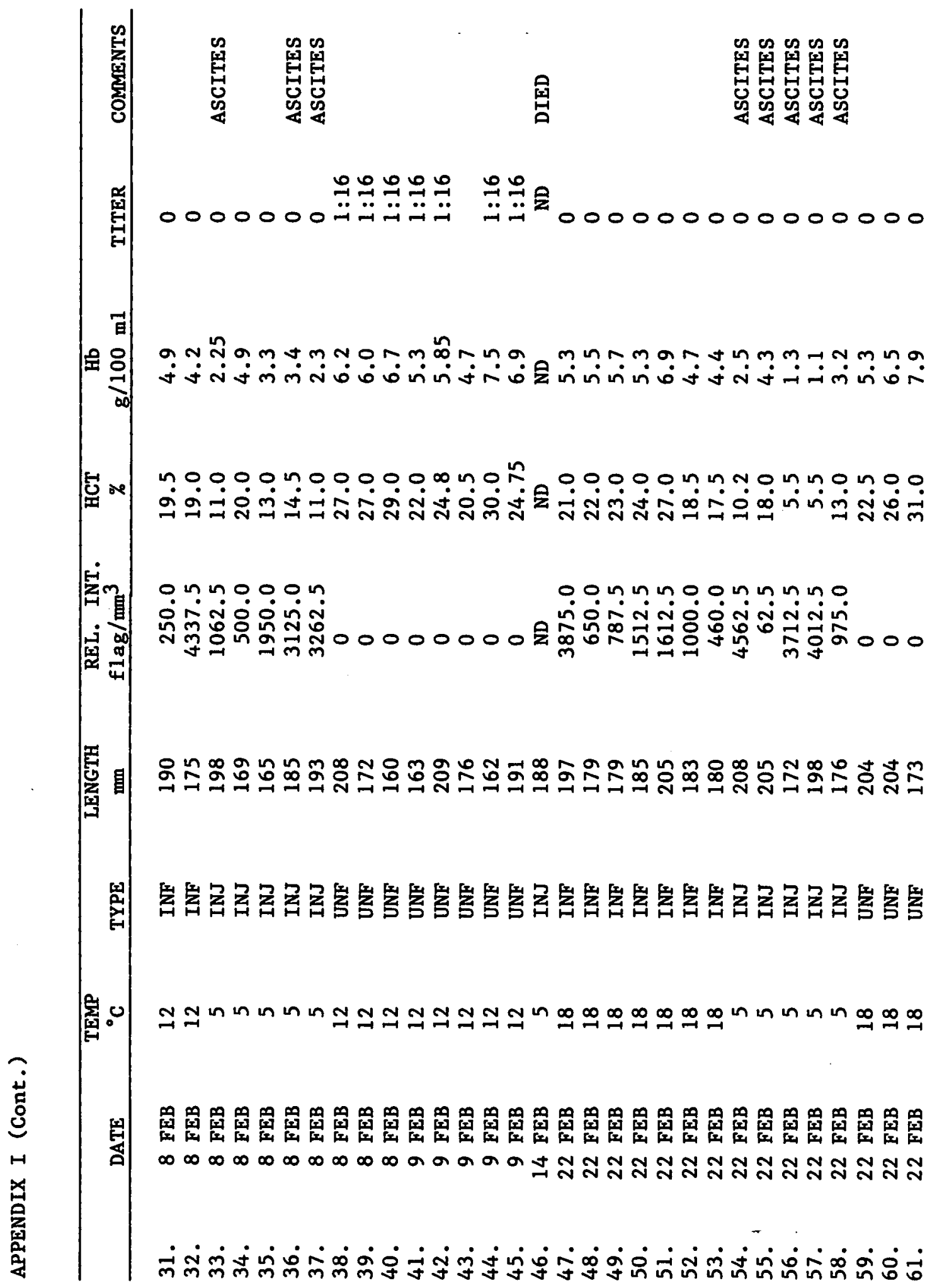




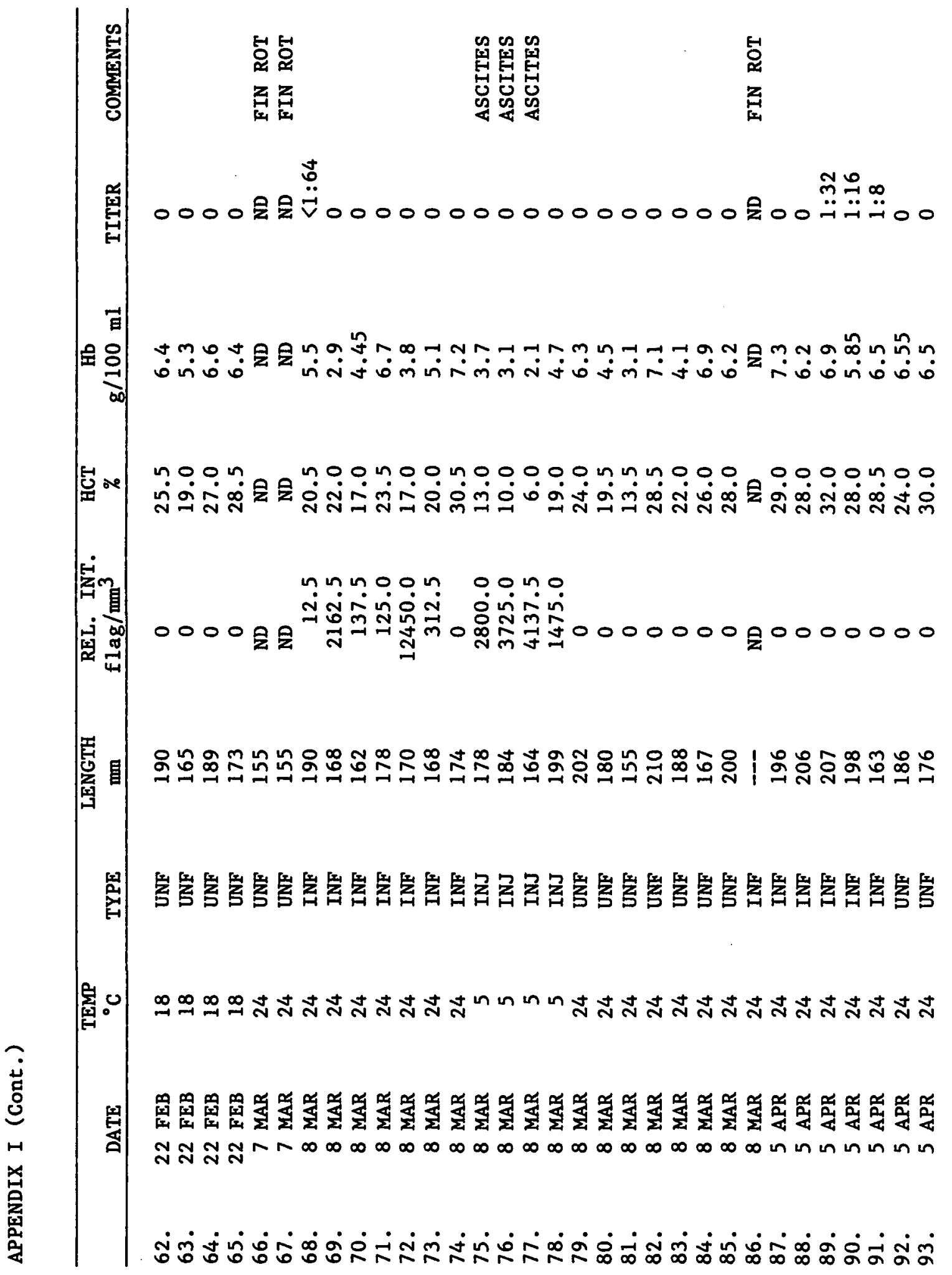




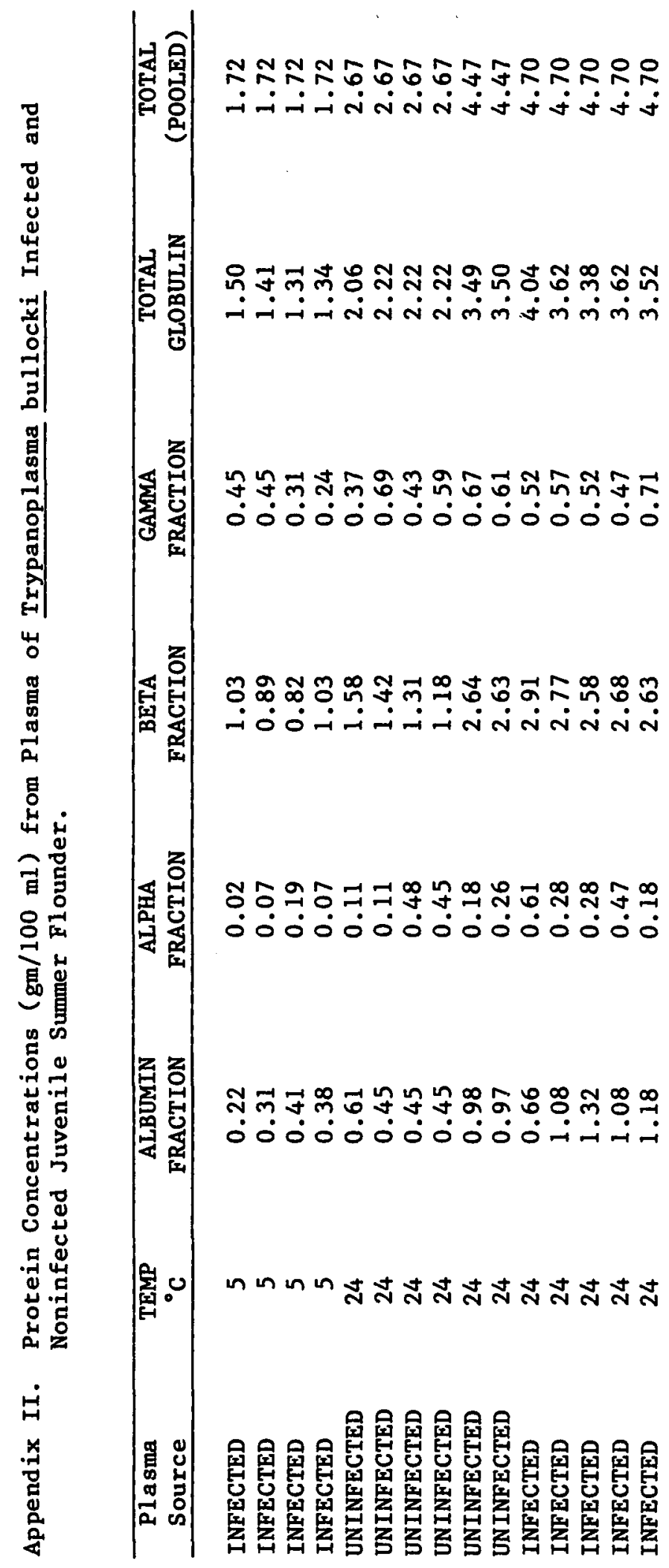


Appendix III. Field Observations on Trypanoplasma bullocki Infected and Noninfected Juvenile Summer Flounder taken from the Lower Chesapeake Bay.

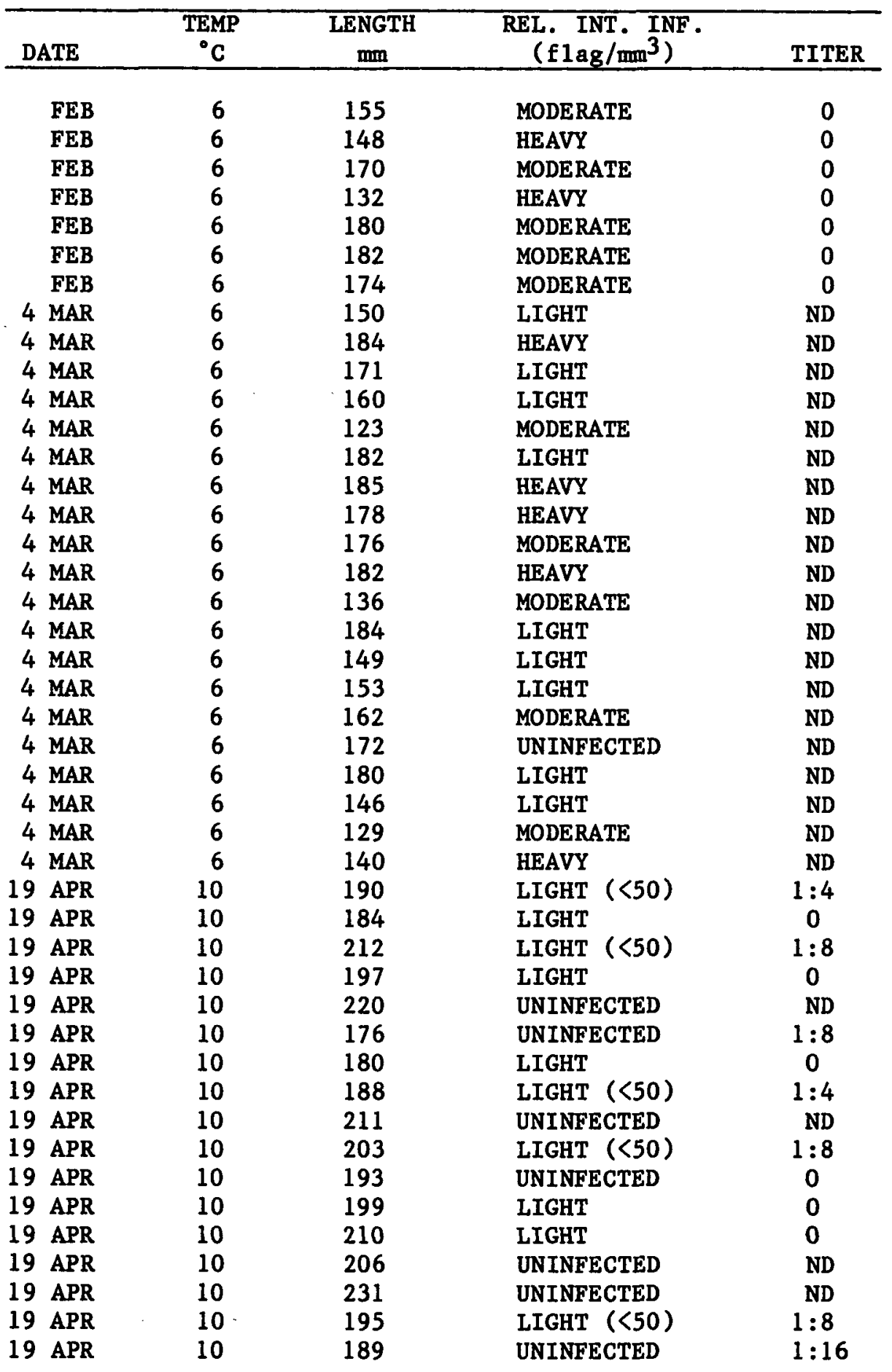


APPENDIX III. (Cont.)

\begin{tabular}{|c|c|c|c|c|}
\hline DATE & $\begin{array}{c}\text { TEMP } \\
{ }^{\circ} \mathrm{C} \\
\end{array}$ & $\begin{array}{c}\text { LENGTH } \\
\text { mm }\end{array}$ & $\begin{array}{l}\text { REL. INT. INF. } \\
\left(\mathrm{flag} / \mathrm{mm}^{3}\right)\end{array}$ & TITER \\
\hline 19 APR & 10 & 211 & LIGHT $(<50)$ & $1: 8$ \\
\hline 19 APR & 10 & 218 & UNINFECTED & ND \\
\hline 19 APR & 10 & 230 & UNINFECTED & ND \\
\hline $3 \mathrm{MAY}$ & 14 & 195 & UNINFECTED & 0 \\
\hline 3 MAY & 14 & 212 & LIGHT & ND \\
\hline 3 MAY & 14 & 182 & UNINFECTED & ND \\
\hline 3 MAY & 14 & 185 & UNINFECTED & ND \\
\hline 3 MAY & 14 & 178 & UNINFECTED & ND \\
\hline 3 MAY & 14 & 165 & LIGHT & ND \\
\hline 3 MAY & 14 & 172 & MODERATE & ND \\
\hline 3 MAY & 14 & 179 & UNINFECTED & ND \\
\hline $3 \mathrm{MAY}$ & 14 & 210 & LIGHT $(<50)$ & $1: 4$ \\
\hline 3 MAY & 14 & 192 & UNINFECTED & $1: 4$ \\
\hline $3 \mathrm{MAY}$ & 14 & 198 & UNINFECTED & $1: 4$ \\
\hline 3 MAY & 14 & 186 & UNINFECTED & $1: 8$ \\
\hline $3 \mathrm{MAY}$ & 14 & 192 & UNINFECTED & 0 \\
\hline $3 \mathrm{MAY}$ & 14 & 194 & UNINFECTED & 0 \\
\hline 3 MAY & 14 & 195 & LIGHT & ND \\
\hline $3 \mathrm{MAY}$ & 14 & 179 & LIGHT & ND \\
\hline 3 MAY & 14 & 182 & LIGHT $(<50)$ & 0 \\
\hline 3 MAY & 14 & 174 & LIGHT & ND \\
\hline 3 MAY & 14 & 202 & UNINFECTED & $1: 8$ \\
\hline 3 MAY & 14 & 190 & LIGHT $(<50)$ & $1: 8$ \\
\hline 3 MAY & 14 & 172 & UNINFECTED & ND \\
\hline 3 MAY & 14 & 197 & LIGHT & ND \\
\hline $3 \mathrm{MAY}$ & 14 & 205 & UNINFECTED & ND \\
\hline 3 MAY & 14 & 190 & UNINFECTED & 0 \\
\hline $3 \mathrm{MAY}$ & 14 & 206 & UNINFECTED & ND \\
\hline 3 MAY & 14 & 182 & UNINFECTED & 0 \\
\hline $3 \mathrm{MAY}$ & 14 & 179 & UNINFECTED & ND \\
\hline $3 \mathrm{MAY}$ & 14 & 176 & LIGHT & ND \\
\hline $3 \mathrm{MAY}$ & 14 & 185 & UNINFECTED & ND \\
\hline $3 \mathrm{MAY}$ & 14 & 176 & UNINFECTED & $1: 8$ \\
\hline 12 MAY & 18 & 190 & UNINFECTED & 0 \\
\hline 12 MAY & 18 & 174 & UNINFECTED & $1: 8$ \\
\hline 12 MAY & 18 & 186 & UNINFECTED & $1: 8$ \\
\hline $12 \mathrm{MAY}$ & 18 & 211 & UNINFECTED & $1: 8$ \\
\hline 12 MAY & 18 & 210 & LIGHT & $\mathbf{0}$ \\
\hline $12 \mathrm{MAY}$ & 18 & 165 & LIGHT $(<50)$ & $1: 8$ \\
\hline $12 \mathrm{MAY}$ & 18 & 154 & LIGHT & 0 \\
\hline 12 MAY & 18 & 227 & LIGHT & ND \\
\hline 12 MAY & 18 & 224 & UNINFECTED & 0 \\
\hline 12 MAY & 18 & 238 & UNINFECTED & ND \\
\hline 12 MAY & 18 & 254 & UN INFECTED & ND \\
\hline $12 \mathrm{MAY}$ & 18 & 224 & LIGHT & ND \\
\hline 12 MAY & 18 & 240 & MODERATE & ND \\
\hline
\end{tabular}


APPENDIX III. (Cont.)

\begin{tabular}{rcclc}
\hline DATE & $\begin{array}{c}\text { TEMP } \\
{ }^{\circ} \mathrm{C}\end{array}$ & $\begin{array}{c}\text { LENGTH } \\
\text { mm }\end{array}$ & $\begin{array}{c}\text { REL. INT. INF. } \\
\text { (flag/mm }{ }^{3}\end{array}$ & TITER \\
\hline 12 MAY & 18 & 268 & LIGHT & ND \\
12 MAY & 18 & 184 & LIGHT & 0 \\
12 MAY & 18 & 212 & UNINFECTED & $1: 8$ \\
12 MAY & 18 & 210 & UNINFECTED & 0 \\
12 MAY & 18 & 218 & UNINFECTED & $1: 8$ \\
12 MAY & 18 & 268 & UNINFECTED & $1: 32$ \\
12 MAY & 18 & 284 & UNINFECTED & $1: 32$ \\
9 JUN & 22 & 206 & UNINFECTED & 0 \\
9 JUN & 22 & 212 & UNINFECTED & $1: 64$ \\
9 JUN & 22 & 210 & UNINFECTED & $1: 64$ \\
9 JUN & 22 & 238 & UNINFECTED & 0 \\
9 JUN & 22 & 230 & UNINFECTED & $1: 64$ \\
9 JUN & 22 & 206 & UNINFECTED & 0 \\
9 JUN & 22 & 210 & UNINFECTED & $1: 64$ \\
9 JUN & 22 & 214 & UNINFECTED & ND \\
9 JUN & 22 & 216 & UNINFECTED & ND \\
9 JUN & 22 & 228 & UNINFECTED & ND \\
9 JUN & 22 & 197 & UNINFECTED & ND \\
9 JUN & 22 & 220 & UNINFECTED & ND \\
9 JUN & 22 & 242 & UNINFECTED & ND \\
9 JUN & 22 & 224 & UNINFECTED & ND \\
9 JUN & 22 & 252 & UNINFECTED & ND \\
9 JUN & 22 & 166 & UNINFECTED & ND \\
9 JUN & 22 & 210 & UNINFECTED & ND \\
9 JUN & 22 & 242 & UNINFECTED & ND \\
9 JUN & 22 & 215 & UNINFECTED & ND \\
9 JUN & 22 & 265 & UNINFECTED & ND \\
9 & & & &
\end{tabular}




\section{LITERATURE CITED}

Avtalion, R. A. 1981. Environmental control of the immune response in fish. Crit. Rev. Environm. Contr. 11:163-188.

Avtalion, R. A., A. Wojdani, Z. Malik, R. Shahrabani and M. Duczyminer. 1973. Influence of environmental temperature on the immune response in fish. Curr. Top. Microbiol. Immunol. 61:1-35.

Baldo, B. A. and T. C. Fletcher. 1973. C-reactive protein-1ike precipitins in plaice. Nature 246:145-146.

Barrow, Jr., J. H. 1954. Observations of some host-specificity and immunological reactions of trypanosome infections in some freshwater fish of Europe. Anat. Rec. 120:750-751.

Barrow, Jr., J. H. 1955. Social behavior in freshwater fish and its effect on resistance to trypanosomes. Proc. Nat. Acad. Sci. $41: 676-679$

Becker, C. D. 1977. Flagellate parasites of fish. Pages 357-416 in J. P. Krier (ed.), Parasitic Protozoa, Vo1. 1. Academic Press, New York.

Becker, C. D. and R. M. Overstreet. 1979. Haematozoa of marine fishes from the northern Gulf of Mexico. J. Fish Dis. 2:469-479. 
Bower, S. M. and P. T. K. Woo. 1977. Cryptobia salmositica:

Incubation in plasma of susceptible and refractile fishes. Exp. Parasit:ol. 43:63-68.

Burreson, E. M. 1982. The life cycle of Trypanoplasma bullocki

(Zoomastigophorea: kinetoplastida). J. Protozoo1. 29:72-77.

Burreson, E. M. and D. E. Zwerner. 1982. The role of host

biology, vector biology, and temperature in the distribution of

Trypanoplasma bullocki infections in the lower Chesapeake Bay.

J. Parasitol. 68:306-313.

Burreson, E. M. and D. E. Zwerner. In press. Juvenile summer

flounder, Paralichthys dentatus, mortalities in the lower

Chesapeake Baty caused by the hemoflagellate, Trypanoplasma

bullocki: Evidence from field and experimental studies. J.

Fish. Dis.

Busch, R. A. 1978. Enteric red mouth disease (Hagerman strain).

Mar. Fish. Rev. 40:42-51.

Cottrel1, B. J. 1977a. A trypanosome from the plaice,

Pleuronectes platessa L. J. Fish. Biol. 11:35-47.

Cottre11, B. J. 1977b. The immune response of plaice

(Pleuronectes platessa L.) to the metacercariae of

Cryptocotyle lingua and Rhipidocotyle johnstonei.

Parasitology 74:93-107. 
Dyková, I. and J. Lom. 1979. Histopathological changes in Trypanosoma danilewskyi Laveran \& Mesnil, 1904 and Trypanoplasma bore11i Laveran \& Mesnil, 1902 infections of goldfish, Carassius auratus (L). J. Fish. Dis. 2:381-390.

Evelyn, T. P. T. 1971. The agglutinin response in sockeye salmon vaccinated intraperitoneally with a heat-killed preparation of the bacterium responsible for salmonid kidney disease. J. Wildl. Dis. $7: 328-335$.

Harris, J. E. 1973. The immune response of dace, Leuciscus leuciscus (L.), to injected antigenic materials. J. Fish. Biol. $5: 261-276$.

Heartwel1 III, C. M. 1975. Immune response and antibody characterization of the channel catfish (Ictalurus punctatus) to a naturally pathogenic bacterium and virus. Tech. Papers U.S. Fish. Wild1. Serv. 85:1-34.

Ingram, G. A. and J. B. Alexander. 1976. The immune response of brown trout (Salmo trutta L.) to injection with soluble antigens. Acta Biol. Med. Germ. 35:1561-1570.

Ingram, G. A. and J. B. Alexander. 1977. Serum protein changes in brout trout (Salmo trutta L. ) after single injections of soluble and cellular antigens. J. Fish. Biol. 11:283-291.

Kohn, J. 1960. Cellulose acetate electrophoresis and immunodiffusion techniques. Pages 56-78 in I. Smith (ed.), 
Chromatographic and Electrophoretic Techniques, Vol. II, Ed. 2. Interscience Publishers, Inc., New York.

Laird, M. and W. L. Bullock. 1969. Marine fish hematozoa from New Brunswick and New England. J. Fish. Res. Bd. Can. $26: 1075-1102$.

Lom, J. 1979. Biology of fish trypanosomes and trypanoplasms. Pages 267-337. in W. H. R. Lumsden and D. A. Evans (eds.), Biology of the kinetoplastida, Vol. 2. Academic Press, New York.

Lowe-Jinde, L. 1979. Some observations of rainbow trout, Salmo gairdneri Richardson, infected with Cryptobia salmositica. J. Fish. Biol. 14:297-302.

Lowe-Jinde, L. 1980. Observations of rainbow trout, Salmo gairdneri Richardson, infected with Cryptobia salmositica. J. Fish. Biol. 17:23-30.

Muroga, K. and S. Egusa. 1969. Immune response of the Japanese eel to Vibrio anguillarum - I. Effects of temperature on agglutinating antibody production in starved eels. Bull. Jap. Soc. Scient. Fish. 35:868-874.

Newman, M. W. 1978. Pathology associated with Cryptobia infection in a summer flounder (Paralichthys dentatus). J. Wild1. Dis. 14:299-304. 
O'Neill, J. G. 1980. Temperature and the primary and the secondary immune responses of three teleosts, Salmo trutta, Cyprinus carpio and Notothenia rossii, to MS2 bacteriophage. Pages 123-130. in M. J. Manning (ed.), Phylogeny of Immunological Memory. Elsevier/North-Holland, New York.

Paterson, W. D. and J. L. Fryer. 1974. Effect of temperature and antigen dose on the antibody response of juvenile coho salmon, (Oncorhynchus kisutch) to Aeromonas salmonicida endotoxin. J. Fish. Res. Bd. Can. 31:1743-1749.

Putz, R. E. 1972. Biological studies on the hemoflagellates Cryptobia cataractae and Cryptobia salmositica. Tech. Papers U.S. Fish. Wild1. Serv. 63:1-25.

Rijkers, G. T., E. M. H. Frederix-Wolters and W. B. Van Muiswinkel. 1980a. The immune system of cyprinid fish, kinetics and temperature dependence of antibody-producing cells in carp (Cyprinus carpio). Immunology $41: 91-97$.

Rijkers, G. T., J. A. M. Wiegerinck, R. Van Oosterom and W. B. Van Muiswinke1. 1980b. Temperature dependence of humoral immunity in carp (Cyprinus carpio). Pages 477-482 in J. B. Solomon (ed.), Aspects of Developmental and Comparative Immunology. Pergamon Press, New York.

Robohm, R. A., C. Brown and R. A. Murchelano. 1979. Comparison of antibodies in marine fish from clean and polluted areas of the 
New York Bight: Relative levels against 36 bacteria. Appl. Environm. Microbio1. 38:248-257.

Robohm, R. A. and D. S. Sparrows. 1981. Evidence of genetic selection of high antibody responders in summer flounder (Paralichthys dentatus) from polluted areas. Develop. Biol. Standard. $49: 273-278$.

Sakai, D. K. 1982. Titration of hemolysin and analysis of primary antibody response in rainbow trout. Bull. Jap. Soc. Scient. Fish. $48: 345-349$.

Stolen, J. S., T. Gahn and J. Nagle. 1982. The humoral antibody formation to erythrocyte antigens in three species of flatfish. Dev. Comp. Immuno1. 6 (Supp1. 1):101.

Strout, R. G. 1965. A new hemoflagellate (Genus Cryptobia) from marine fishes of northern New England. J. Parasitol. $51: 654-659$.

Trump, G. N. and W. H. Hildeman. 1970. Antibody responses of goldfish to bovine serum albumin. Primary and secondary responses. Immunology 19:621-627.

Wales, J. H. and H. Wolf. 1955. Three protozoan diseases of trout in California. Calif. Fish Game 41:183-187.

Wehnert, S. D. and P. T. K. Woo. 1980. In vivo and in vitro studies on the host specificity of Trypanoplasma salmositica. J. Wildl. Dis, 16:183-187. 
Woo, P. T. K. 1979. Trypanoplasma salmositica: Experimental infections in rainbow trout, Salmo gairdneri. Exp. Parasitol. 47:36-48.

Woo, P. T. K. 1981. Acquired resistance against Trypanosoma danilewskyi in goldfish, Carrassius auratus. Parasitology $83: 343-346$. 


\section{VITA}

\section{Joseph Pau1 Sypek}

Born in Chicopee, Massachusetts on 24 October 1954. Graduated from Cathedral High, Springfield, Massachusetts in June, 1972.

Received a B.A. with honors, in Biology from American International College, Springfield in May, 1976. Received a M.A. in Animal Pathology from the University of Rhode Island, Kingston in May, 1979. Entered the College of William and Mary, School of Marine Science in August, 1979. Received a National Institute of Health post doctoral research fellowship in immunology at Tuft's University, School of Medicine, Boston, Massachusetts commencing in September, 1982. 